\title{
Chemistry of Supraglacial Ponds in the Debris-Covered Area of Lirung Glacier in Central Nepal Himalayas
}

\author{
Maya P. Bhatt ${ }^{1,3} \cdot$ Nozomu Takeuchi $^{2} \cdot$ Miguel F. Acevedo ${ }^{3}$
}

Received: 26 February 2015/ Accepted: 18 August 2015/Published online: 27 August 2015

(C) Springer Science+Business Media Dordrecht 2015

\begin{abstract}
Glacial meltwater samples were collected from 15 supraglacial ponds at elevations ranging between 3989 and $4292 \mathrm{~m}$ above sea level in the debris-covered area of Lirung glacier in central Nepal Himalayas, from November 2010 to October 2011 on a bimonthly basis. We examined elevation trends, and their control by seasonality, dominant geochemical processes, and seasonal dynamics in these supraglacial ponds. Concentration of some parameters showed a decreasing trend with elevation but with high variability and modulation by seasons, being more prevalent in the post-monsoon. Sulfate is the only parameter showing significant elevation trends regardless of the season, although the trend is also affected by the monsoon. The concentrations of major chemical solutes were highest during post-monsoon season and lower in the pre-monsoon and monsoon seasons, indicating influence of seasonality on dissolution, dilution, and hydrological processes. Contribution to chemical loads from marine aerosols to these pond water appeared to be minor except for sodium and magnesium. Chemical weathering of carbonate and silicate minerals fueled by dissolution of pyrite appeared as the dominant geochemical processes.
\end{abstract}

Keywords Supraglacial ponds - Weathering - Central Himalaya - Sulfide minerals · Debris covered $\cdot$ Lirung glacier

Maya P. Bhatt

bhatt.maya@yahoo.com

1 Institute for the Biogeochemistry and Marine Chemistry, KlimaCampus - University of Hamburg, Bundesstrasse 55, 20146 Hamburg, Germany

2 Department of Earth Sciences, Chiba University, Chiba 263-5822, Japan

3 Department of Electrical Engineering, Institute of Applied Sciences, University of North Texas, Denton, TX 76203-5017, USA 


\section{Introduction}

\subsection{Background}

Water from ice melt from the Himalayas constitutes the major water resources in Nepal; most of the major rivers of Nepal, including Karnali, Koshi, and Narayani, originate from glaciers in the Himalayas. For example, the headwater of Narayani is located at Langtang glacier in central Nepal. Himalayan glaciers are melting rapidly due to continued rising of Earth's temperature causing hydrological changes in the river headwater. Particularly in the debris-covered area of valley glaciers, a number of supraglacial ponds or lakes are formed by ice melt and sometimes collapse due to rock and moraine falls to the ponds or lakes. Many glacial lakes are reported in the debris area of the glaciers around the world as well as in Himalayas (Lliboutry et al. 1977; Kirkbride 1993; Takeuchi and Kohshima 2000; Sakai et al. 1998; Bhatt et al. 2007; Sakai and Fujita 2010; Sakai 2012; Benn et al. 2012; Takeuchi et al. 2012).

Supraglacial ponds on Himalayan glaciers are increasing in size; for example, the Tsho Rolpa glacier lake in the Gaurishankar Himalaya in Nepal has increased its size more than sevenfold in the last four decades (WWF-Nepal 2005). Rise in temperature increases the probability of glacial lake outburst flood (GLOF) events in the region, in turn, causing catastrophic consequences in downstream communities (Yamada and Sharma 1993). These events could result in loss of lives, natural resources, and infrastructure and property worth millions of dollars (Yamada and Sharma 1993; Richardson and Reynolds 2000; ICIMODUNEP 2002; Kattelmann 2003). There are 2323 glacier lakes in Nepal of which 20 are potentially dangerous, and 12 GLOF events have already been observed in Nepal since 1960 (ICIMOD 2011).

Thick debris cover resists the ablation process (Sakai et al. 2000), and the occurrence of high turbidity (suspended sediments) in supraglacial ponds within debris-covered area plays a great role in glacier melting (Takeuchi et al. 2012). Debris-covered glaciers exhibit more retreat than the other glaciers in the central Himalaya region; this is probably due to the presence of thin debris and highly turbid ponds as they absorb more heat and accelerate the ablation processes within the debris area (Sakai et al. 2000; Takeuchi et al. 2012).

Based on observations during 2000-2008, Scherler et al. (2011) reported that the majority of glaciers within Hindu Kush Himalayan region are retreating. In the worlds' glaciers, retreating rate varies with the landscape position and the actual rates and mechanisms are still subject to debate. Low-elevation glaciers in central Himalaya are retreating with a rapid rate probably due to deposition of black carbon based on the visual observation. However, the contribution to black carbon seems insignificant in melting most glaciers in high Himalayan glaciers (Ming et al. 2013).

The first denudation studies from Nepal Himalaya reported high rates of chemical erosion (Bhatt et al. 2000). At the outlet point of Lirung debris-covered glacier in central Nepal Himalaya, chemical erosion rate is higher than those reported for the Antarctic, Arctic, and European glaciers (Sharp et al. 1995; Wadham et al. 1998; Bhatt et al. 2000; Green et al. 2005). Debris may have played a great role in the release of solute from this catchment. Uplift and erosion, tectonic recycling of sediment, drives high denudation rate in many active mountain belts (Stallard 2000; Stallard and Edmond 1983; Gaillardet et al. 1999; West et al. 2005; Bhatt and McDowell 2007; Gabet 2007) together with climatic conditions of that basin (McDowell and Asbury 1994; White and Blum 1995; Hartmann 2009; Bookhagen 2010; Gabet et al. 2010; Hirschmiller et al. 2014). Air temperature and 
precipitation control glacier melting and hydrolysis conditions of glaciered basins, thus modulating dissolution rates of the minerals of such basins according to the seasons (Bhatt et al. 2000, 2007). Water chemistry and dominance of weathering processes in a basin primarily depend on the underlying bedrocks and soil types of the basin.

Chemistry of glacial meltwater, supraglacial ponds, glacier lakes, and ice core studies have been documented from the Himalayan region of Nepal (Kamiyama 1984; Watanabe et al. 1984; Jenkins et al. 1995; Reynolds et al. 1995; West et al. 2002; France-Lanord et al. 2003; Quade et al. 2003; Evans et al. 2004; Tipper et al. 2006; Barnard et al. 2006; Bhatt et al. 2000, 2007, 2008, 2009; Wolff-Boenisch et al. 2009; Lupker et al. 2012), yet it is important to attain a better understanding of the spatial and temporal variability of water chemistry and its relationship with weathering processes in this region.

Bhatt et al. (2007) conclude that the dominant processes determining the chemical composition of glacier pond water within debris area of Lirung glacier are sulfide oxidation coupled with carbonate dissolution and chemical weathering of aluminosilicate.

The oxidation of pyrite can be written as (Drever 1988)

$$
\mathrm{FeS}_{2}+3.75 \mathrm{O}_{2}+3.5 \mathrm{H}_{2} \mathrm{O} \rightarrow \mathrm{Fe}(\mathrm{OH})_{3} \text { Precip }+2 \mathrm{SO}_{4}^{2-}+4 \mathrm{H}^{+}
$$

Carbonate and dolomite dissolution takes place as follows:

$$
\begin{gathered}
\mathrm{CaCO}_{3}+\mathrm{CO}_{2}(\mathrm{aq})+\mathrm{H}_{2} \mathrm{O} \rightarrow \mathrm{Ca}^{2+}+2 \mathrm{HCO}_{3}^{-} \\
\mathrm{CaMg}\left(\mathrm{CO}_{3}\right)_{2}+\mathrm{CO}_{2}(\mathrm{aq})+2 \mathrm{H}_{2} \mathrm{O} \rightarrow \mathrm{Ca}^{2+}+\mathrm{Mg}^{2+}+4 \mathrm{HCO}_{3}^{-}
\end{gathered}
$$

The major aluminosilicate dissolution reactions taking place within debris area of Lirung glacier constructed based on the pioneering work of Garrels and Mackenzie (1967) for Na-feldspar, Ca-feldspar, K-feldspar, and biotite are as follows:

$$
\begin{gathered}
2 \mathrm{NaAlSi}_{3} \mathrm{O}_{8}+2 \mathrm{CO}_{2}+3 \mathrm{H}_{2} \mathrm{O} \rightarrow \mathrm{Al}_{2} \mathrm{Si}_{2} \mathrm{O}_{5}(\mathrm{OH})_{4}+2 \mathrm{Na}^{+}+2 \mathrm{HCO}_{3}^{-}+4 \mathrm{SiO}_{2} \\
\mathrm{CaAl}_{2} \mathrm{Si}_{2} \mathrm{O}_{8}+2 \mathrm{CO}_{2}+4 \mathrm{H}_{2} \mathrm{O} \rightarrow \mathrm{Al}(\mathrm{OH})_{3}+2 \mathrm{Ca}^{2+}+2 \mathrm{HCO}_{3}^{-}+2 \mathrm{SiO}_{2} \\
\mathrm{KAlSi}_{3} \mathrm{O}_{8}+2 \mathrm{CO}_{2}+3 \mathrm{H}_{2} \mathrm{O} \rightarrow \mathrm{Al}_{2} \mathrm{Si}_{2} \mathrm{O}_{5}(\mathrm{OH})_{4}+2 \mathrm{~K}^{+}+2 \mathrm{HCO}_{3}^{-}+4 \mathrm{SiO}_{2} \\
\mathrm{KMg}_{3} \mathrm{AlSi}_{3} \mathrm{O}_{10}(\mathrm{OH})_{2}+7 \mathrm{CO}_{2}+3.5 \mathrm{H}_{2} \mathrm{O} \rightarrow \\
\mathrm{Al}_{2} \mathrm{Si}_{2} \mathrm{O}_{5}(\mathrm{OH})_{4}+3 \mathrm{Mg}^{2+}+\mathrm{K}^{+}+7 \mathrm{HCO}_{3}^{-} \\
+2 \mathrm{SiO}_{2}
\end{gathered}
$$

In Bhatt et al. (2007), we studied water from supraglacial ponds in the debris-covered area of Lirung glacier during the pre-monsoon to post-monsoon period of 1996 and compared to the water at the glacier outlet. This debris-covered area is a very dynamic environment, and the pond sizes and positions change based on weather, landslides, and avalanches. Therefore, we choose to research the same area 15 years later (2010-2011) and measure water quality parameters bimonthly during a full year in order to better understand the seasonality of geochemical processes. In addition, we included measurements of inorganic carbon at the end of the study because of lack of reports of variation in inorganic carbon species from this region.

There were many changes observed regarding size and position of lakes within the basin. In this paper, we report our findings of this second sample collection and the data represent now a unique picture of a system changed after the major earthquake of April 2015; landslides and avalanches wiped out the Langtang village and severely destroyed the base camp at Kyangjin, and hundreds of people lost their lives in the region. The size and position of lakes drastically changed after the earthquake within the debris area. 


\subsection{Objectives and Hypotheses}

The main objectives of this new study are to confirm our previous results regarding dominant geochemical processes and to further examine the variations among ponds and the effects of seasonality on the geochemical processes in this debris-covered glacier system. Our major research question is how does seasonality affects the hydrological regime of this system and elevation patterns of water constituents among the ponds. To study this question, we propose four hypotheses:

- Research Hypothesis 1 There are elevation gradients for some water quality parameters in the ponds showing increasing concentration with decreasing elevation. The corresponding null hypothesis $\mathrm{HO}$ to test is that there is no trend in elevation for all of the solutes.

- Research Hypothesis 2 These elevation gradients would be more clearly marked during the pre-monsoon and post-monsoon seasons, and become more variable during the monsoon when the flows are higher. The corresponding null hypothesis $\mathrm{H} 0$ to test is that elevation trends are the same regardless of season.

- Research Hypothesis 3 The main source of sulfate ions is from the oxidation of pyrite which fuels the dissolution process of minerals such as carbonates (providing calcium) and aluminosilicates (providing magnesium). The corresponding null hypothesis $\mathrm{H} 0$ to test is that there is no relationship between sulfate and base cations calcium and magnesium.

- Research Hypothesis 4 There is a characteristic temporal pattern showing minimum values at the pre-monsoon, followed by increasing concentrations in the monsoon due to runoff, and a maximum at the post-monsoon when water freezes. Subsequent melting later in the post-monsoon leads to decrease in concentration to the premonsoon. The corresponding null hypothesis $\mathrm{H} 0$ to test is that there is no difference in values between post-monsoon and pre-monsoon for all water parameter.

\section{Study Area}

\subsection{Site Description}

The Langtang mountain range $\left(28^{\circ} 13^{\prime} 01.9^{\prime \prime} \mathrm{N}, 85^{\circ} 33^{\prime} 42.0^{\prime \prime} \mathrm{E}\right)$ is located in the central Nepal Himalayas (Fig. 1). The Lirung glacier is a debris-covered glacier in the Langtang valley and about $60 \mathrm{~km}$ north of the capital city Kathmandu. The highest point in this range is a peak of Mt. Langtang Lirung, $7234 \mathrm{~m}$ a.s.l. The study area was the debris-covered area on Lirung glacier ranging between 3989 and $4292 \mathrm{~m}$ a.s.l. in elevation (Fig. 1). The total basin area of the Lirung glacier is $13.8 \mathrm{~km}^{2}$ of which $33 \%$ has high relief and is covered with bare rocks, $16 \%$ correspond to debris-covered glaciers (nonvegetated and covered with rocks, boulders, cobbles, and talus with thin soils), and the rest (51\%) is glacier covered (Fukusima et al. 1987). Human influence is more intense in lower-elevation sites, but limited to seasonal settlement and livestock grazing.

\subsection{Geologic Setting}

The geology of the Himalayan basin consists of four units from north to south separated by major thrust systems: the Tethyan Sedimentary Series (TSS), the High Himalaya 

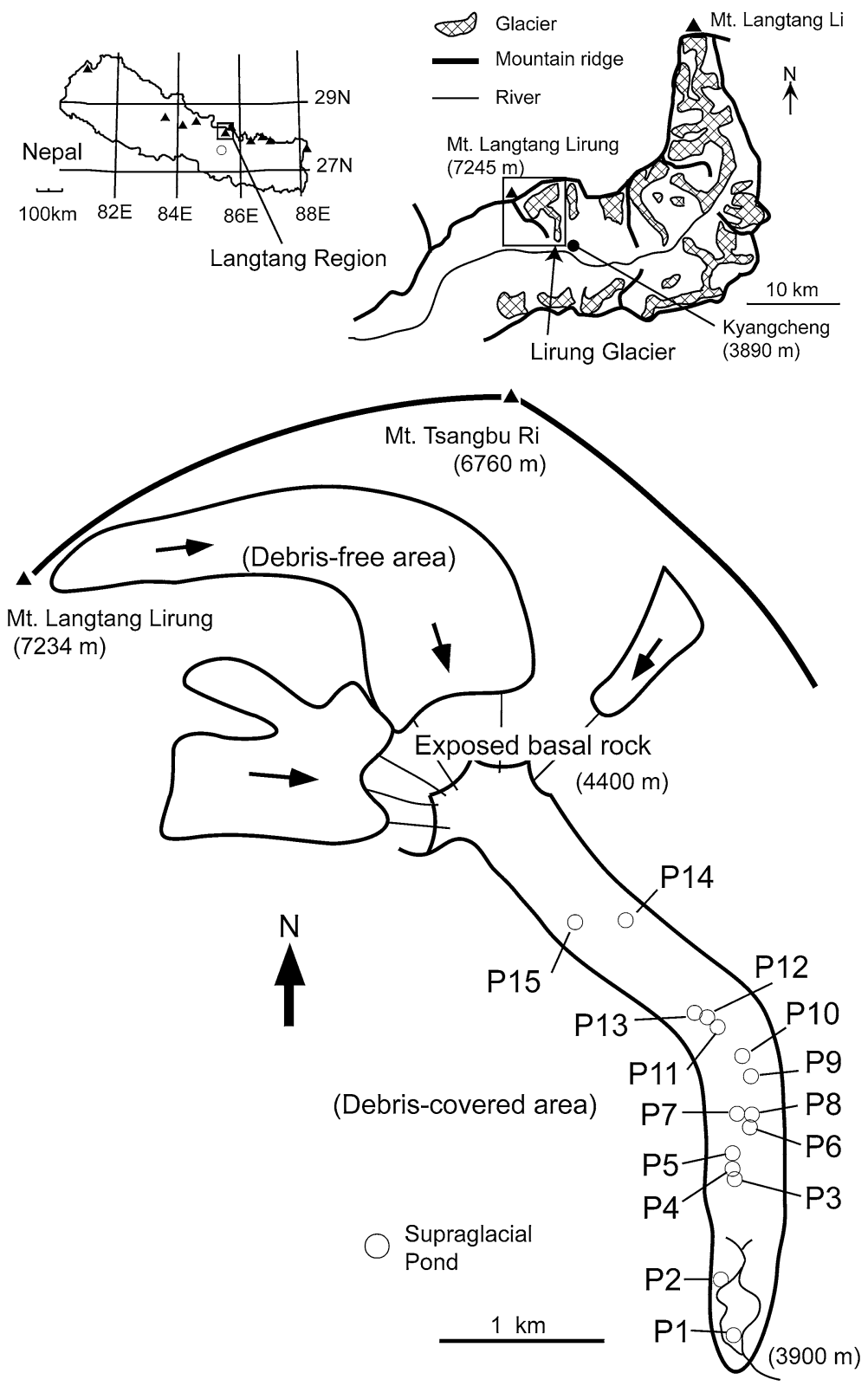

Fig. 1 Location of Lirung glacier in central Nepal Himalaya with sampling sites of supraglacial ponds in debris-covered area of the glacier

Crystalline (HHC), the Lesser Himalaya (LH), and the Siwaliks (Chabaux et al. 2001; France-Lanord et al. 2003). The Langtang valley lies in a complex transition zone between the HHC metasediments in the south and TSS in the north. The Langtang valley is primarily underlain by high-grade metamorphic rocks with traces of igneous rocks including migmatities, gneisses, schists, phyllites, and granites (Inger and Harris 1992). The glacier 
bedrock consists of biotite, quartz, plagioclase with minor amount of muscovite, alkali feldspar, ilmenite, and sillimanite based on the X-ray fluorescence analysis of rock samples from the debris area of Lirung glacier (Bhatt et al. 2008). The Cryothents, cryumbrepts, and lithic types of soils are dominant in the high-elevation area of Langtang valley (SD 1984). The presence of sulfide-bearing minerals such as pyrite, galena, sphalerite, and chalcopyrite enhances the dissolution rates of minerals within the basin (Bhatt et al. 2007). The gray phyllites and grilstones with conglomerates with white massive quartzites, basic intrusion, gray calcareous slates and carbonates, and thick beds of gray siliceous dolomites are found in the high mountain region of central Nepal Himalaya (DMG 1980, 1994).

\section{Materials and Methods}

\subsection{Sample Collection}

Glacier meltwater sampling was carried out at the 15 supraglacial ponds in the debris-covered area from fall 2010 to fall 2011 (Fig. 1; Table 1). Ponds P1 through P13 were measured on a bimonthly basis. Two additional ponds, P14 and P15, located at higher elevation were measured in October 2011. Based on visual observation of turbidity, three types of ponds were found within the debris area: blue type—very clear water, yellow type-slightly turbid water, and green type-highly turbid water with ice walls. We assessed color of each pond qualitatively based on combination of these three basic water colors (Table 1).

Each water sample was filtered through a pre-combusted glass microfiber filter (Whatmann $\mathrm{GF} / \mathrm{F}$ ) with a pore size $0.45 \mu \mathrm{m}$ in the field for the dissolved organic carbon (DOC) samples and polycarbonate microfiber filter with a pore size of $0.45 \mu \mathrm{m}$ for the major ions and dissolved silica analysis. Supraglacial pond water samples were collected in $100 \mathrm{~mL}$ acid-washed polyethylene bottles and kept refrigerated in Kathmandu and then frozen to transport to the Institute of Biogeochemistry and Marine Chemistry of the University of Hamburg for analysis. Dissolved silica samples were refrigerated only. The DOC samples were taken in $30 \mathrm{~mL}$ glass vials in which $30 \mu \mathrm{L}$ of phosphoric acid was added just after the filtration in the field. The alkalinity samples were collected in $200 \mathrm{~mL}$ polyethylene bottles in which $200 \mu \mathrm{L}$ of mercuric chloride was added just after sampling to prevent microbial activity. Pre-weighted filter papers were used to measure the suspended sediment (SS) in each sample.

In the field, water temperature, electrical conductivity (EC) and $\mathrm{pH}$ were measured by thermometer, EC meter (Hanna), and $\mathrm{pH}$ meter (Hanna), respectively, for all ponds in October 2011.

\subsection{Analytical Methods}

SS was measured by gravimetric methods applied to the $47-\mathrm{mm} \mathrm{GF} / \mathrm{F}$ and polycarbonate microfiber filter after drying in a vacuum oven at $40{ }^{\circ} \mathrm{C}$ for $48 \mathrm{~h}$. Alkalinity was determined by acid titration method (APHA 1995). Detection limits for SS and alkalinity were 1 and $0.1 \mathrm{mg} \mathrm{L}^{-1}$, respectively. Dissolved silica $\left(\mathrm{SiO}_{2}\right)$ was analyzed by DR 3800 spectrophotometer (HACH Company) with the standard molybdenum blue 8185 method.

Major cations $\left(\mathrm{Na}^{+}, \mathrm{K}^{+}, \mathrm{Mg}^{2+}, \mathrm{Ca}^{2+}\right.$, and $\left.\mathrm{NH}_{4}^{+}\right)$and anions $\left(\mathrm{F}^{-}, \mathrm{Cl}^{-}, \mathrm{NO}_{2}{ }^{-}, \mathrm{NO}_{3}{ }^{-}\right.$, and $\mathrm{SO}_{4}{ }^{2-}$ ) were determined by cation (Compact IC pro-cation) and anion (Compact IC pro-anion) chromatography, respectively. Anions were measured with a Metrohm selfregenerating suppressor MSM $\left(50 \mathrm{mmol} \mathrm{L}{ }^{-1} \mathrm{H}_{2} \mathrm{SO}_{4}\right)$ and analytical column Metrosep A SUPP 5-250. Cations were measured with a Metrohm 881 (C4) cation separation column 


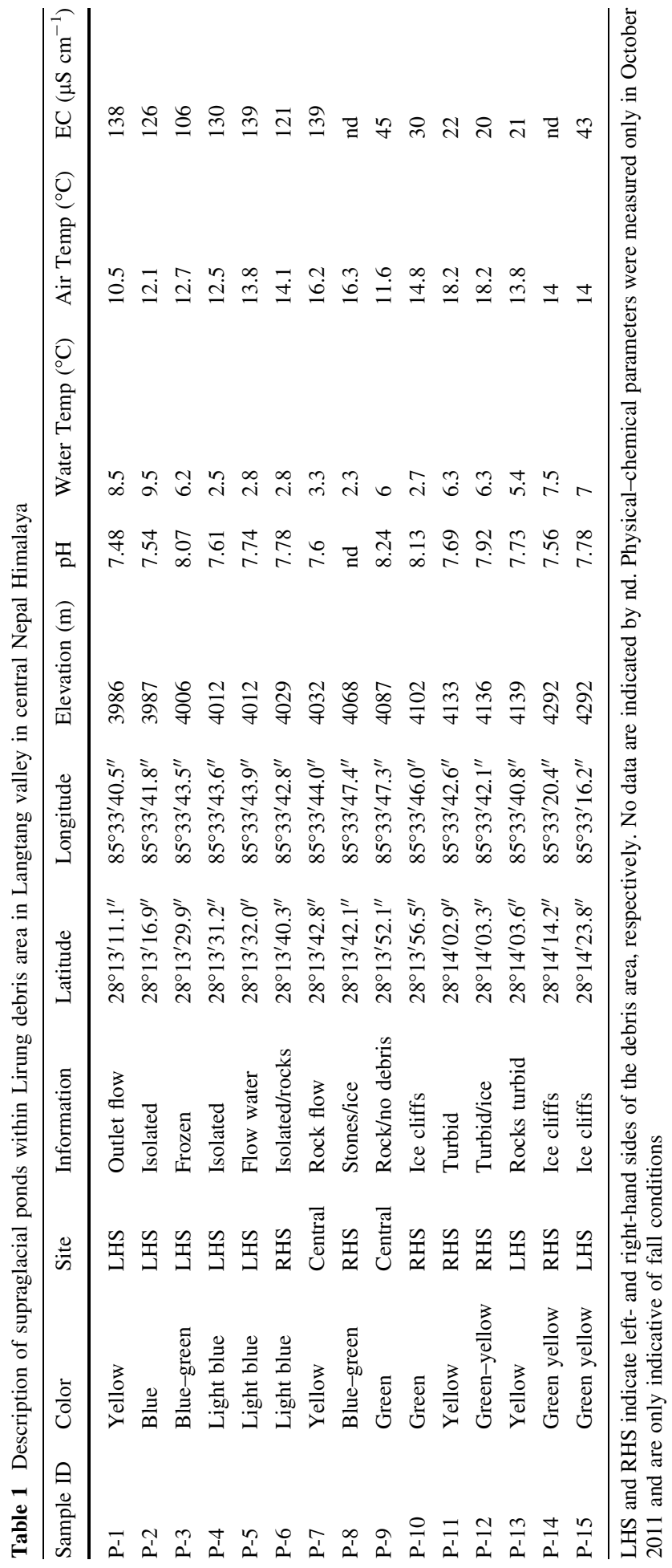


$150 \mathrm{~mm}$ long and conductivity detection. Analytical errors were $<2 \%$ for $\mathrm{Cl}^{-}, \mathrm{NO}_{3}{ }^{-}$, $\mathrm{SO}_{4}{ }^{2-}, \mathrm{Na}^{+}, \mathrm{K}^{+}, \mathrm{Mg}^{2+}, \mathrm{Ca}^{2+}$, and $\mathrm{SiO}_{2},<4 \%$ for $\mathrm{NH}_{4}{ }^{+}$, and $<5 \%$ for $\mathrm{PO}_{4}-\mathrm{P}$. Total dissolved nitrogen (TDN) and DOC were measured with high-temperature Pt-catalyzed combustion using a Shimadzu TOC- $\mathrm{V}_{\mathrm{CSH}}$ with a total nitrogen measuring unit. Dissolved organic nitrogen (DON) was calculated by subtracting inorganic nitrogen from TDN. Marine aerosol contribution to different elements was corrected by using molar ratios of different elements as reported in earlier studies (Keene et al. 1986; McDowell et al. 1990; Millot et al. 2002; Bhatt and McDowell 2007). Marine aerosol contribution to pond waters was corrected for $\mathrm{Na}^{+}, \mathrm{K}^{+}, \mathrm{Mg}^{2+}, \mathrm{Ca}^{2+}$, and $\mathrm{SO}_{4}{ }^{2-}$ by using concentration of chloride as reference species and the sea-salt-corrected chemical species represented with an asterisk.

\subsection{Statistical Analysis}

Relationship of concentration of chemical parameters with pond category such as color is examined by boxplots and ANOVA. To test the null for hypothesis 1, elevation patterns are examined by linear regression. These regressions are performed by season in order to test the null of hypothesis 2 . Relationship of calcium and magnesium with sulfate was examined by linear regression to test the null of hypothesis 3 . The average of major parameters over all ponds was calculated per month to emphasize temporal variations. Points at nonsampled months (December, February, April, June, and August) are linearly interpolated for each pond and then averaged over all ponds. This interpolation is for visualization purposes only. We did not include ponds 14 and 15 in the seasonal analysis because these ponds were measured only in October 2011. To test the null corresponding to hypothesis 4, we used paired $t$ test of maxima and minima values in the year across ponds for each water parameter. Weathering patterns are visualized by ternary diagrams for anions and cations. All statistical analysis and graphics were performed by the R program version 3.2.1 (R Development Core Team 2015). Ternary diagrams were prepared using the ggtern package of $\mathrm{R}$.

\section{Results}

\subsection{Overview and Composition of Major Ions}

In October 2011, water temperature of observed ponds was $4.73{ }^{\circ} \mathrm{C}$ in average and ranged from 1.6 to $7.85{ }^{\circ} \mathrm{C}$; such variation was due to the difference in sampling time and ice presence among the ponds. Air temperature ranged from 7.0 to $18.2{ }^{\circ} \mathrm{C}$, and variation is linked with the difference in sampling time. SS for those months averaged $43 \mathrm{mg} \mathrm{L}^{-1}$ and ranged from 16 to $141 \mathrm{mg} \mathrm{L}^{-1}$. SS was much higher at pond P1 which is close to the Lirung outlet point (which collects the main water flow of the debris-covered area) and much lower in ponds with ice cliffs and the ponds in higher elevation sites (Table 2).

Composition of major cations was $\mathrm{Ca}^{2+} \gg \mathrm{Na}^{+}>\mathrm{K}^{+}>\mathrm{NH}_{4}^{+}>\mathrm{Mg}^{2+}$; however, concentration varies widely due to specific site conditions (Table 2). The major anion compositions were alkalinity $>\mathrm{SO}_{4}{ }^{2-} \gg \mathrm{Cl}^{-}>\mathrm{NO}_{3}{ }^{-} \gg \mathrm{F}^{-}$. The charge balance error (CBE) was less than $8 \%$ for samples P1 to P6 in low-elevation sites, but it was less than $13.7 \%$ for all samples within the debris area. The cause for this discrepancy is not clear, but we assume it may be due to unmeasured organic acids.

Average concentrations of $* \mathrm{Na},{ }^{*} \mathrm{~K}, * \mathrm{Mg},{ }^{*} \mathrm{Ca}$, and $* \mathrm{SO}_{4}$ after sea-salt correction and elemental ratios are presented in Table 3 . The contribution to concentrations of $* \mathrm{Na}, * \mathrm{~K}$, 


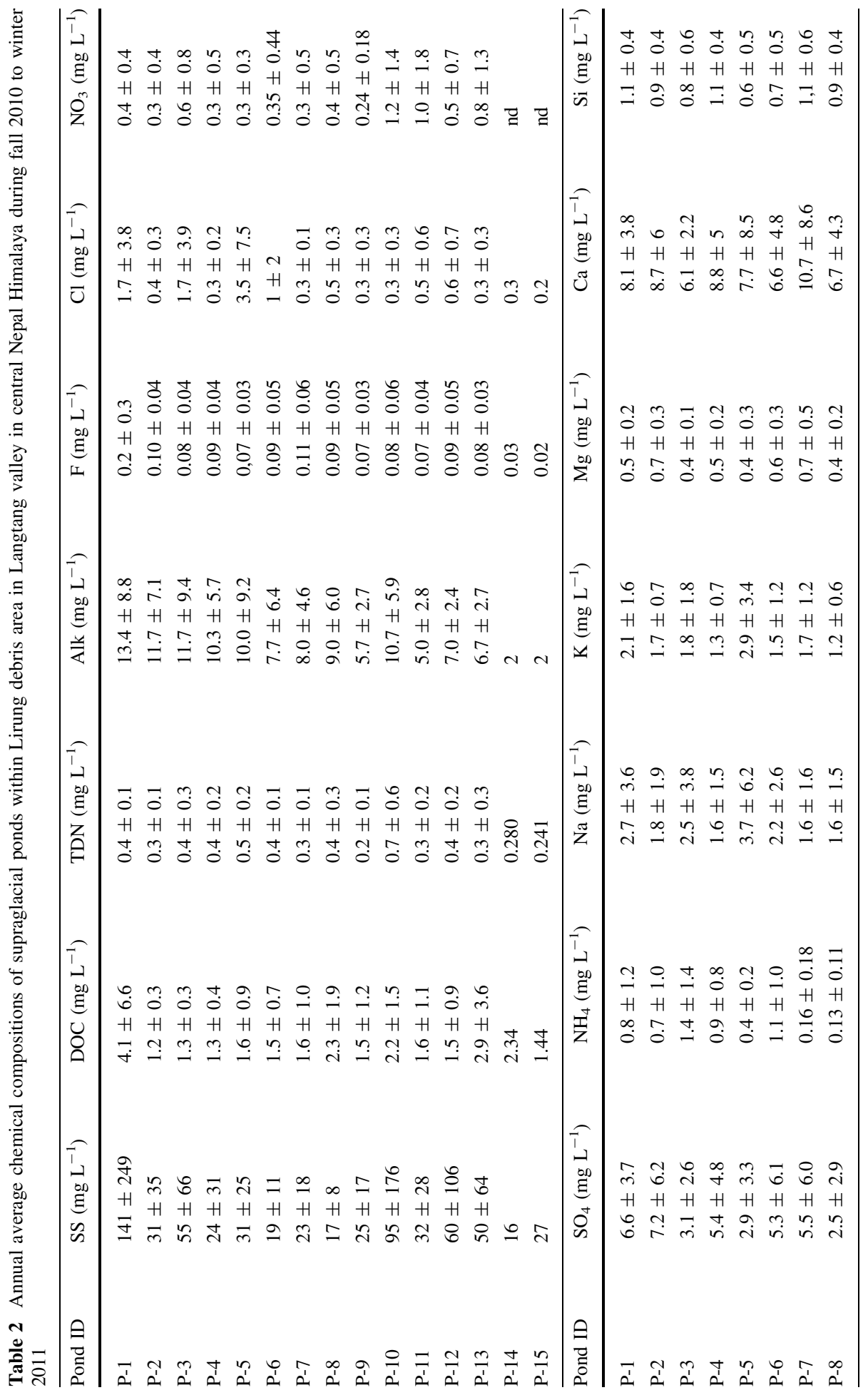




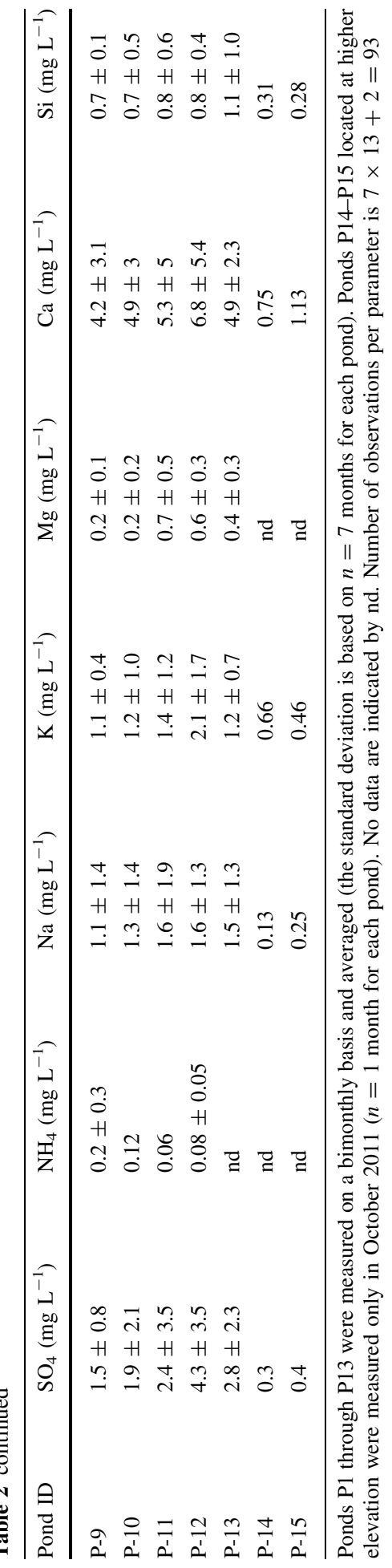




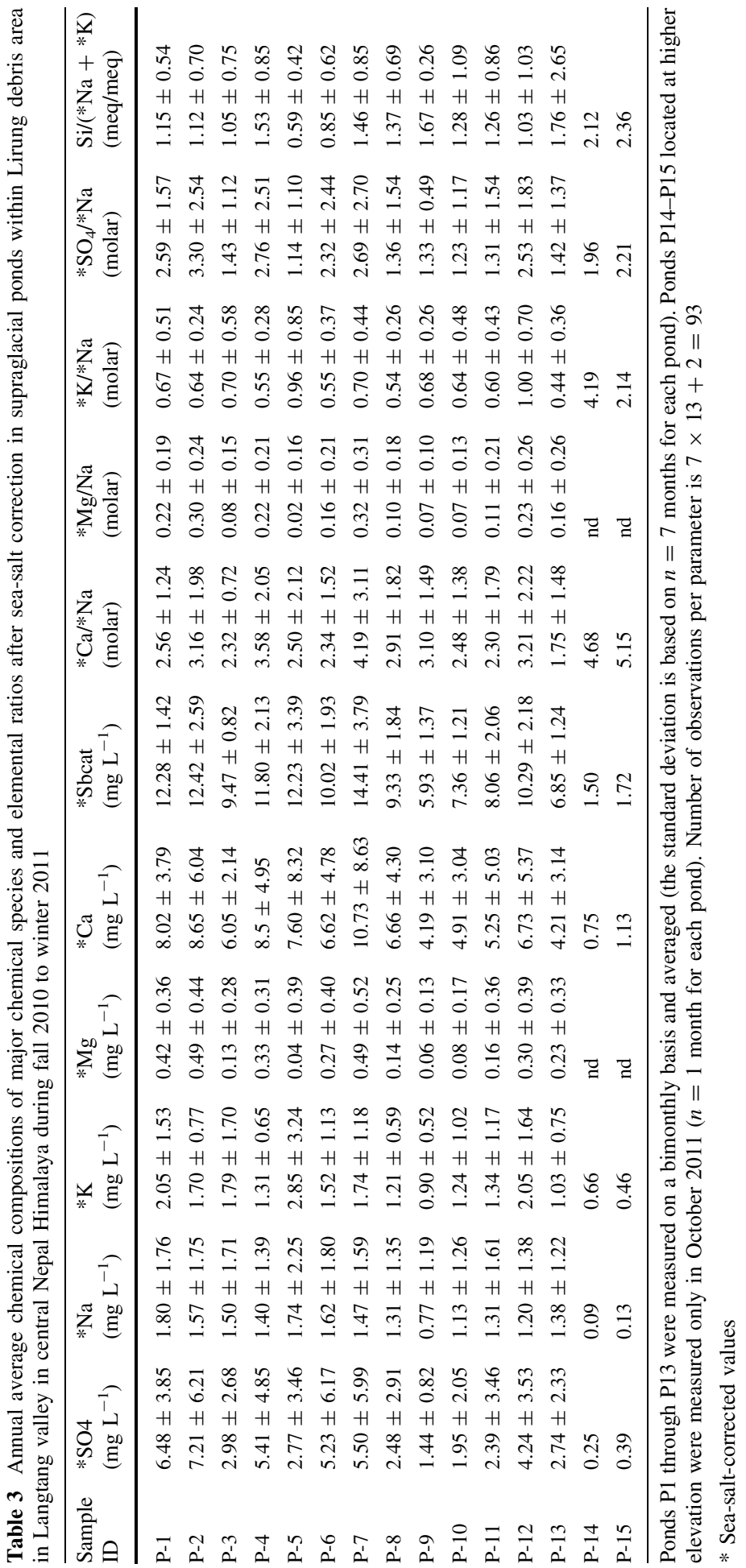


$* \mathrm{Mg}, * \mathrm{Ca}$, and $* \mathrm{SO}_{4}$ from rock weathering appeared as 75.8, 99.0, 90.2, 99.7, and $98.5 \%$ to their total concentrations, respectively. This result suggests that lithology has dominant control on the chemistry of pond waters, while contribution to $\mathrm{Na}$ and $\mathrm{Mg}$ from sea-salt aerosols is minor. Contribution to marine aerosols varied with the specific site locations of the ponds and showed highest contribution in pond P5 and lowest contribution in pond P7 showing influence of landscape position. Calcium appeared as a dominant ion among all measured chemical species and released mostly (99.7 \%) from rock and soil dissolution. The sum of sodium and potassium after sea-salt correction contributes $32 \%$, and the sum of calcium and magnesium after sea-salt correction contributes $68 \%$ to the total sum of cations among all the ponds.

Phosphate concentration was not detected in several ponds. Fluoride contributes $0.7 \%$ to total sum of anions. Average nitrate concentration was $0.52 \mathrm{mg} \mathrm{L}^{-1}$ and contributed $4 \%$ to the total sum of anions. Sulfate concentration after sea-salt correction appeared as a dominant anion with average concentration of $3.4 \mathrm{mg} \mathrm{L}^{-1}$ and ranged $0.25-7.21 \mathrm{mg} \mathrm{L}^{-1}$. Sulfate contributes $25 \%$ to total sum of anions. Average alkalinity was $7.4 \mathrm{mg} \mathrm{L}^{-1}$ with the range $2-13.4 \mathrm{mg} \mathrm{L}^{-1}$ and contributes $64.6 \%$ to total sum of anions.

\subsection{Hypothesis 1: Elevation Trends}

In general, color varied with elevation (ANOVA $p$ value $=0.017$ ), progressing from blue to green and then green to yellow, except yellow that occurs from low to middle elevation (Fig. 2a). The $\mathrm{pH}$ of the ponds (measured in October 2011) was basic, showing a
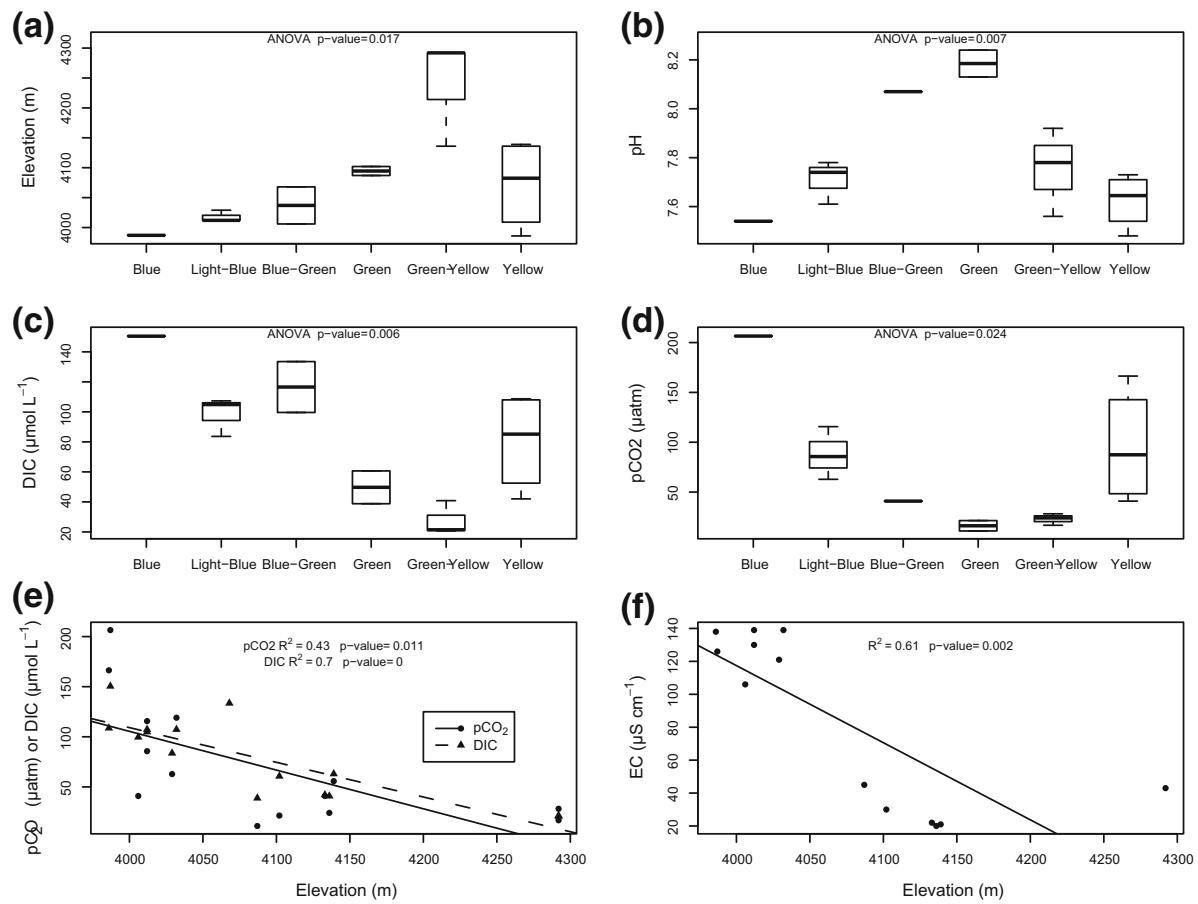

Fig. 2 Boxplots variation in pond elevation and some water parameters measured in October 2011 with pond color. Scatter plots some water parameters measured in October 2011 versus elevation 
Table 4 Inorganic carbon species in supraglacial ponds within Lirung debris area in Langtang valley in central Nepal Himalaya during winter 2011

\begin{tabular}{lccccccr}
\hline $\begin{array}{l}\text { Sample } \\
\text { ID }\end{array}$ & $\mathrm{pH}$ & $\begin{array}{l}\text { Alkalinity } \\
\left(\mu \mathrm{mol} \mathrm{L}{ }^{-1}\right)\end{array}$ & $\left.\begin{array}{l}\mathrm{DIC} \\
(\mu \mathrm{mol} \mathrm{L}\end{array}{ }^{-1}\right)$ & $\begin{array}{l}\mathrm{CO}_{2} \\
\left.(\mu \mathrm{mol} \mathrm{L})^{-1}\right)\end{array}$ & $\begin{array}{l}\mathrm{HCO}_{3} \\
\left.(\mu \mathrm{mol} \mathrm{L})^{-1}\right)\end{array}$ & $\begin{array}{l}\mathrm{CO}_{3} \\
\left(\mu \mathrm{mol} \mathrm{L}^{-1}\right)\end{array}$ & $\begin{array}{r}\mathrm{pCO}_{2} \\
(\mu \mathrm{atm})\end{array}$ \\
\hline P-1 & 7.68 & 99.9 & 108.7 & 9.4 & 98.9 & 0.11 & 166.4 \\
P-2 & 7.72 & 139.9 & 150.4 & 11.3 & 138.6 & 0.18 & 206.5 \\
P-3 & 7.29 & 99.9 & 99.6 & 2.5 & 96.4 & 0.37 & 40.9 \\
P-4 & 7.28 & 99.9 & 107.3 & 8.2 & 98.8 & 0.12 & 115.6 \\
P-5 & 7.74 & 99.9 & 104.9 & 6.0 & 98.5 & 0.16 & 85.6 \\
P-6 & 7.78 & 79.9 & 83.7 & 4.4 & 79.0 & 0.14 & 62.8 \\
P-7 & 7.60 & 99.9 & 107.3 & 8.1 & 98.8 & 0.12 & 119.0 \\
P-8 & nd & 99.9 & 133.5 & 33.7 & 99.6 & 0.03 & 473.3 \\
P-9 & 8.24 & 40.0 & 38.8 & 0.7 & 37.8 & 0.20 & 11.0 \\
P-10 & 8.13 & 59.9 & 60.7 & 1.5 & 58.9 & 0.22 & 21.4 \\
P-11 & 7.69 & 40.0 & 42.0 & 2.5 & 39.4 & 0.06 & 40.9 \\
P-12 & 7.92 & 40.0 & 40.8 & 1.5 & 39.2 & 0.10 & 24.1 \\
P-13 & 7.73 & 59.9 & 63.0 & 3.5 & 59.4 & 0.09 & 55.8 \\
P-14 & 7.56 & 20.0 & 21.4 & 1.7 & 19.8 & 0.02 & 28.2 \\
P-15 & 7.78 & 20.0 & 20.6 & 1.0 & 19.6 & 0.04 & 16.7 \\
\hline
\end{tabular}

significant variation with pond color being highest for blue-green and green ponds (Table 1; Fig. 2b).

The concentration of inorganic carbon species measured in October 2011 is compiled in Table 4. Among the inorganic carbon species, bicarbonate has the dominant control. Dissolved inorganic carbon (DIC) has higher concentration in blue-type ponds followed by yellow and green types of ponds (Fig. 2c). Similarly to DIC, $\mathrm{pCO}_{2}$ has higher concentration in blue-type ponds followed by yellow and green types of ponds (Fig. 2d). A blue-type isolated pond (P2) showed highest amount of DIC in which bicarbonate and carbonate also appeared highest on this pond, while the $\mathrm{CO}_{2}$ and $\mathrm{pCO}_{2}$ appeared highest in pond $\mathrm{P} 8$ in the middle section. This pond, P8, was covered with ice, and there was big ice cliff fall on the pond just before sampling, so the $\mathrm{CO}_{2}$ and $\mathrm{pCO}_{2}$ appeared exceptionally high in this pond. Based on the $\mathrm{pCO}_{2}$ data, all the ponds except $\mathrm{P} 8$ are unsaturated with carbon dioxide content.

DIC showed significant decreasing trend of concentration with increasing elevation with $R^{2}=0.75, p$ value $=3.6 \times 10^{-5}$ (Fig. $2 \mathrm{e}$ ). The contribution of $\mathrm{pCO}_{2}$ to the total DIC also decreases with increasing elevation. After discarding the value in P8 as no data, a linear regression of $\mathrm{pCO}_{2}$ versus elevation yielded low coefficient of determination but clear trend $\left(R^{2}=0.38, p\right.$ value $\left.=0.011\right)$. These results allow to reject the null $\mathrm{H} 0$ corresponding to hypothesis 1 .

EC decreases significantly with increased elevation (Table 1; Fig. 2f) also allowing to reject the $\mathrm{H} 0$ corresponding to hypothesis 1 . EC has higher concentration in blue-type ponds than green type of ponds; however, EC in yellow ponds varies widely and had values as high as in blue ponds and as low in green ponds. This indicates that EC is more a function of elevation than of color (not shown in the figure; ANOVA, nonsignificant $p$ value $=0.228$.

Most major ions showed slightly higher concentration in the lower-elevation sites than in the high-elevation sites except nitrate that shows increasing trend (Tables 2, 3). 

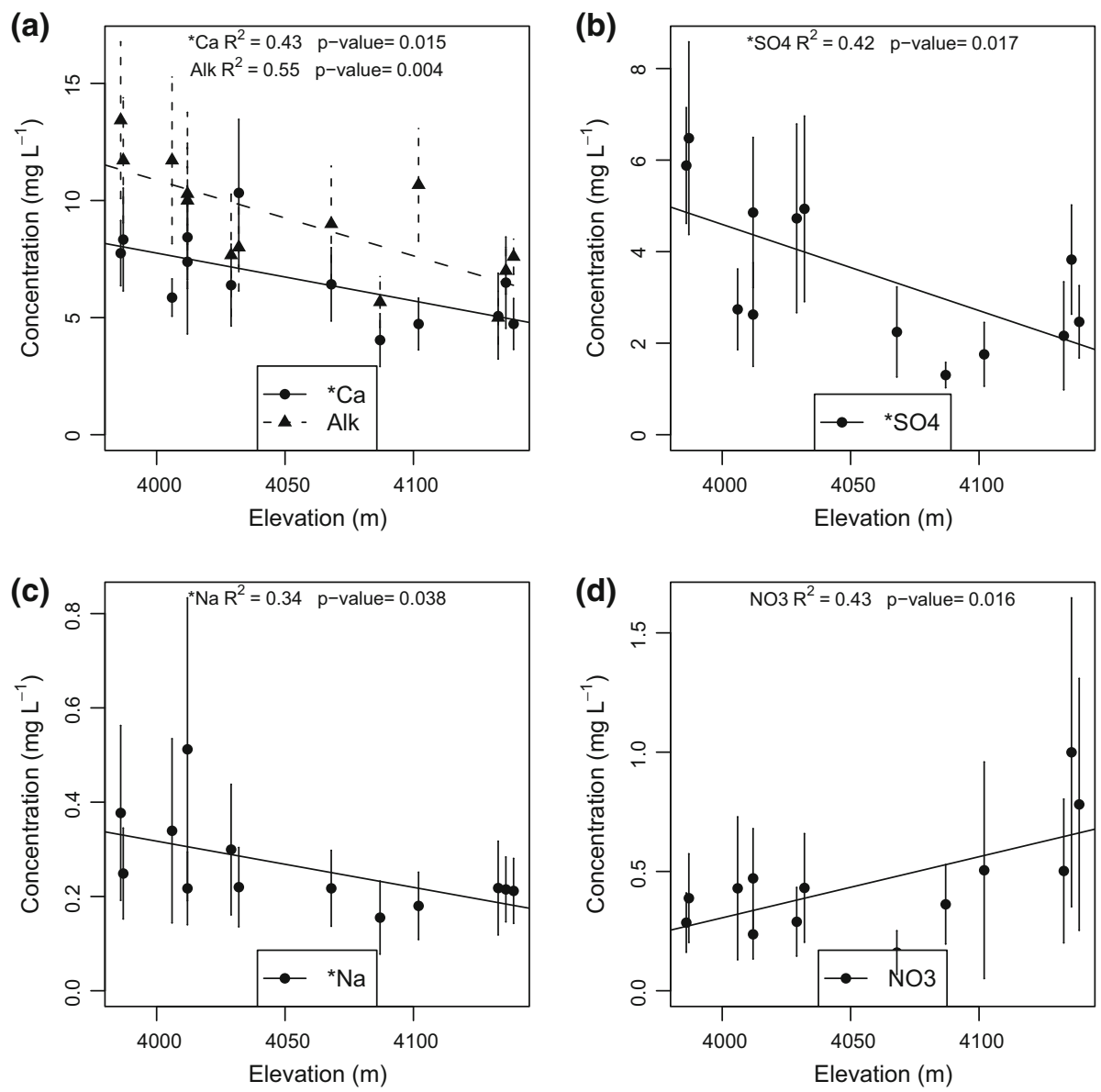

Fig. 3 Altitudinal gradient of the annual average of those chemical parameters that resulted in significant variation with elevation. All trends are negative except nitrate that shows an increasing trend

Elevation trends of the annual averages reported in these tables are significant for some parameters: alkalinity, ${ }^{*} \mathrm{Ca},{ }^{*} \mathrm{SO}_{4}, * \mathrm{Na}$, and $\mathrm{NO}_{3}$ (Fig. 3), allowing rejecting the $\mathrm{H} 0$ for hypothesis 1 . Thus, there are elevation trends for some water parameters.

There was no pattern of variation in major ions with respect to color of the pond, except for $* \mathrm{SO}_{4}$ which exhibits the lowest concentration in purely green ponds. Sulfate is relatively significant $(p=0.064)$ variation with color being lowest for blue-green and green ponds (graph not shown).

Table 2 indicates that the lowest Si concentration was observed in the uppermost pond (P15) and the highest in a central pond (P7) in which the main flow mixes with pond water; this water appeared highly turbid due to the presence of cobbles and soils from moraine falls. In general, the silicon concentration showed no decreasing trends of concentration with increasing elevation. DOC and TDN did not show a significant increasing trend with elevation. 
(a)

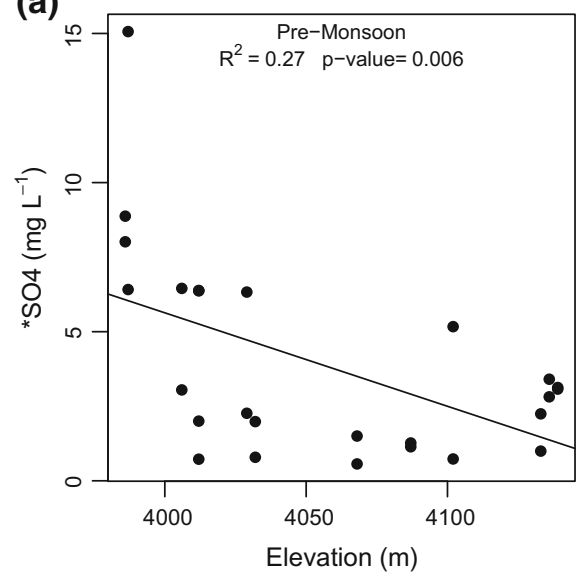

(c)

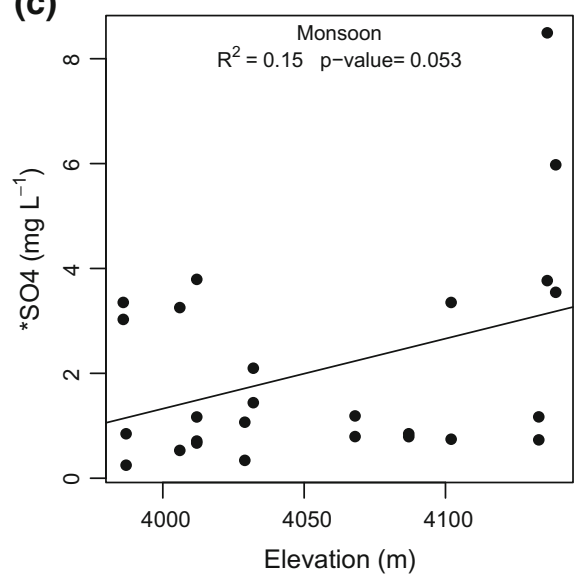

(b)

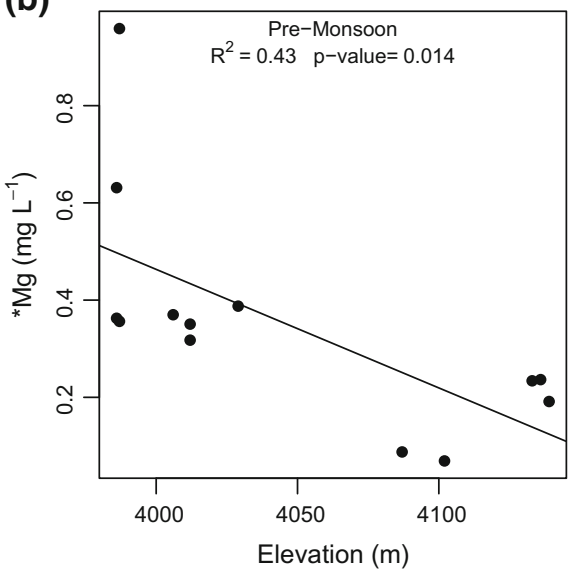

(d)

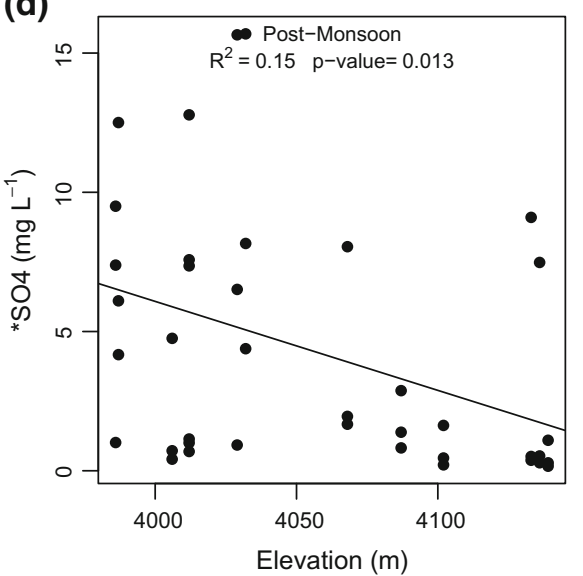

Fig. 4 Altitudinal variations in sulfate and magnesium. Sulfate shows a significant trend for all seasons but weaker during monsoon. $\mathrm{Mg}$ is significant only for the pre-monsoon

\subsection{Hypothesis 2: Seasonal Changes in Elevation Trends}

Sulfate shows significant differences regardless of season (Fig. 4a, c, d) with quite low $p$ values 0.006 and 0.013 for pre-monsoon and post-monsoon. It is also significant for the monsoon months but shows an increasing trend and less significant $p$ value $=0.053$. These results allow to reject the $\mathrm{H} 0$ corresponding to hypothesis 2 , and thus, some elevation trends vary with the seasons. *Mg varies the same way in the pre-monsoon (Fig. 4b) correlating with sulfate as further explored later. Several parameters, F, alkalinity, ${ }^{*} \mathrm{~K}$, and ${ }^{*} \mathrm{Ca}$, showed a significant trend with elevation only for the post-monsoon season (Fig. 5), demonstrating again the seasonal influence of elevation patterns and supporting hypothesis 2 .

\subsection{Hypothesis 3: Dominant Geochemical Processes}

The sea-salt-corrected cations * $\mathrm{Ca}$ and $* \mathrm{Mg}$ showed a significant relationship with sulfate for all seasons (Fig. 6 a, c, e). The slope for ${ }^{*} \mathrm{Ca}$ is about 20 times higher than $* \mathrm{Mg}$. The 

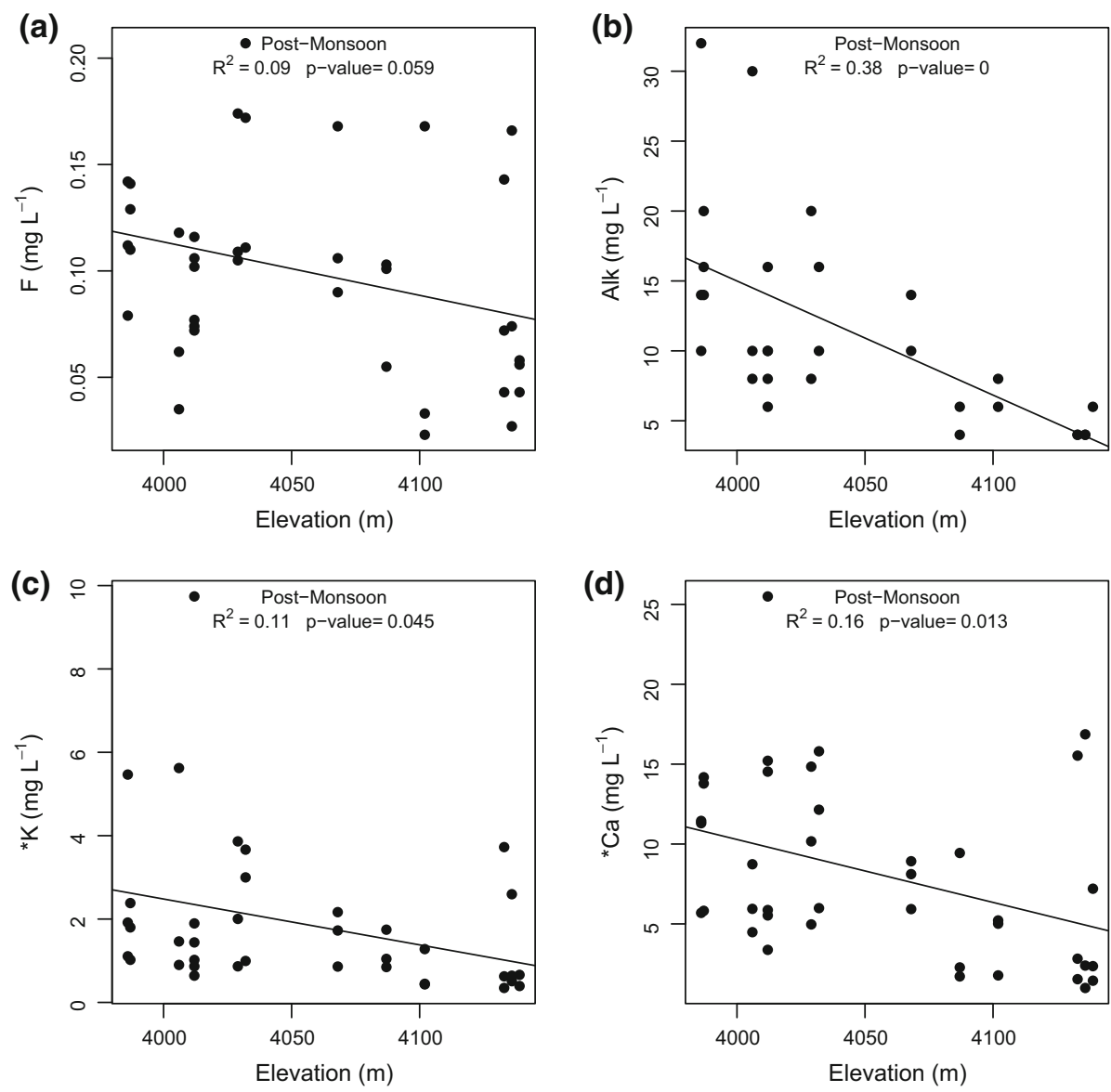

Fig. 5 Altitudinal variations in some chemical parameters that resulted significant during post-monsoon

coefficient of determination is high for the pre-monsoon and post-monsoon months (Fig. 6a, e), suggesting that both parameters are released by similar geochemical process. In fact, there is a strong correlation between $* \mathrm{Mg}+{ }^{*} \mathrm{Ca}$ and $* \mathrm{SO}_{4}$ for the pre-monsoon (Fig. 6b). The relationship between $* \mathrm{Mg}+* \mathrm{Ca}$ and $* \mathrm{SO}_{4}$ is also relatively significant for post-monsoon months (Fig. 6f) but not for monsoon months (Fig. 6d). These results allow to reject the H0 corresponding to hypothesis 3 , and thus, we conclude that there is a relationship between oxidation of pyrite and dissolution of carbonates and aluminosilicates.

The contributions to sodium and potassium after sea-salt correction accounted for $32 \%$ of the total sum of base cations suggesting more contribution to these ions due to intense dissolution of silicate minerals within the basin. Ratio of silicon to sum of sodium and potassium after sea-salt correction $\mathrm{Si} /\left(* \mathrm{Na}+{ }^{*} \mathrm{~K}\right)$ averages $\sim 1.5$ although it is highly variable (Table 3), indicating silicate weathering in this system. There is high variability variation in this ratio $\mathrm{Si} /(* \mathrm{Na}+* \mathrm{~K})$ with no significant trend with elevation (regression with $R^{2}=\sim 0.0, p$ value $\left.=0.89\right)$.

Figure 7 a shows a ternary diagram for major cations $\left(* \mathrm{Ca}, * \mathrm{Na},{ }^{*} \mathrm{~K}\right)$. We do not include * Mg because all values are very low and in this case dolomite does not contribute significantly. Most of the points fall within the calcium-potassium line suggesting carbonate 
(a)

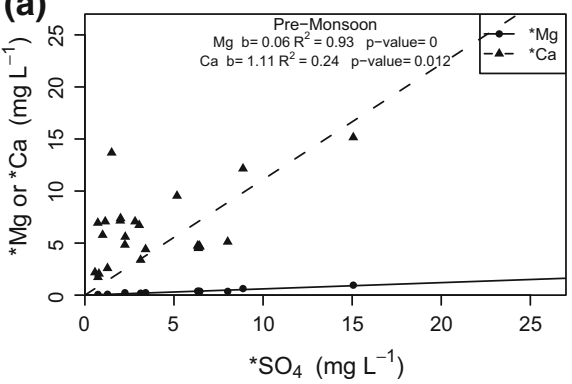

(c)

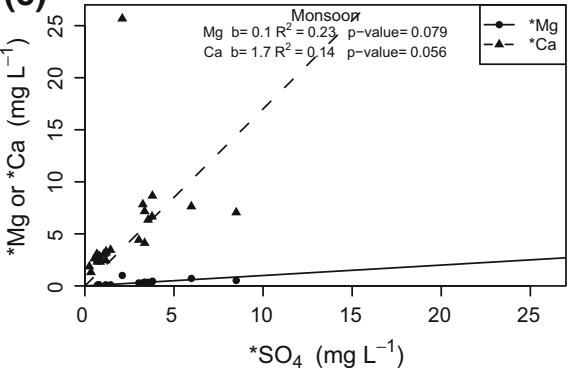

(e)

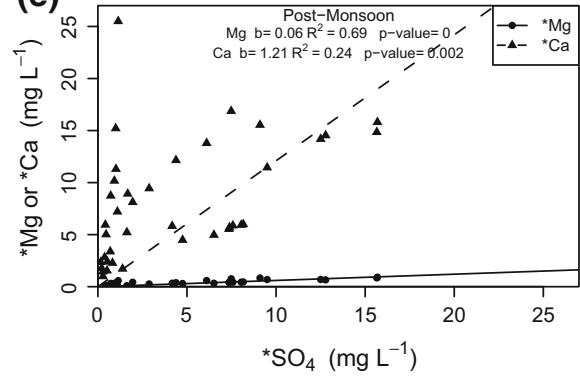

(b)

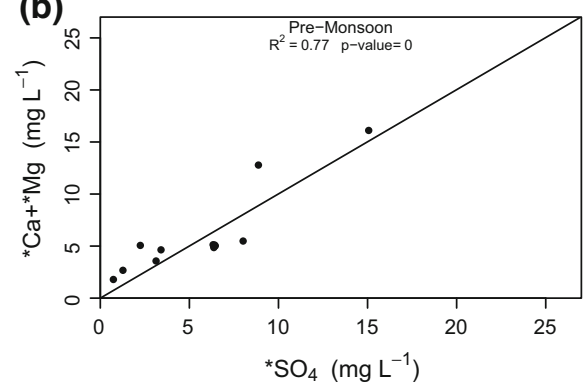

(d)

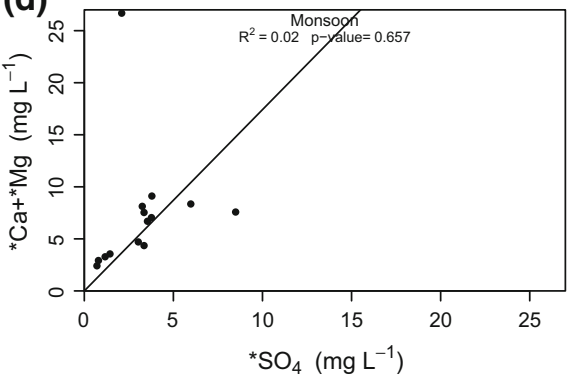

(f)

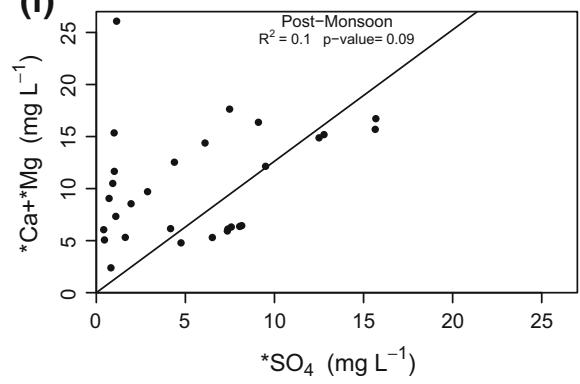

Fig. 6 Relationship between sulfate and calcium, magnesium, and calcium plus magnesium illustrating relative contributions and variation by season

and plagioclase dissolution as the predominant geochemical processes. Many points stretch toward the sodium apex especially during post-monsoon season in lower-elevation sites, indicating the role of hydrolysis and temperature to enhance the dissolution of aluminosilicates, primarily plagioclase.

Figure $7 \mathrm{~b}$ shows a ternary diagram using alkalinity, $\mathrm{Cl}$, and $* \mathrm{SO}_{4}$ to represent composition of major anions. Most of the points lying along the sulfate alkalinity line suggesting clearly that the oxidation of pyrite coupled with the dissolution of carbonate and aluminosilicate primarily plagioclase appeared as dominant geochemical processes in the area. Some of the points scattered toward chloride apex especially during monsoon and post-monsoon season, suggesting contribution from evaporative minerals due to favorable hydrolysis condition.

The contribution of sea-salt to sulfate is negligible in the central Himalayan region. In average, sulfate contributes nearly $25 \%$ to total anions and alkalinity contributes less than $64.6 \%$ to total anions among the ponds in the debris area. 
(a)

\section{Cations}

Season

O Pre-Monsoon

$\square$ Monsoon

$\triangle$ Post-Monsoon

Elevation (m)
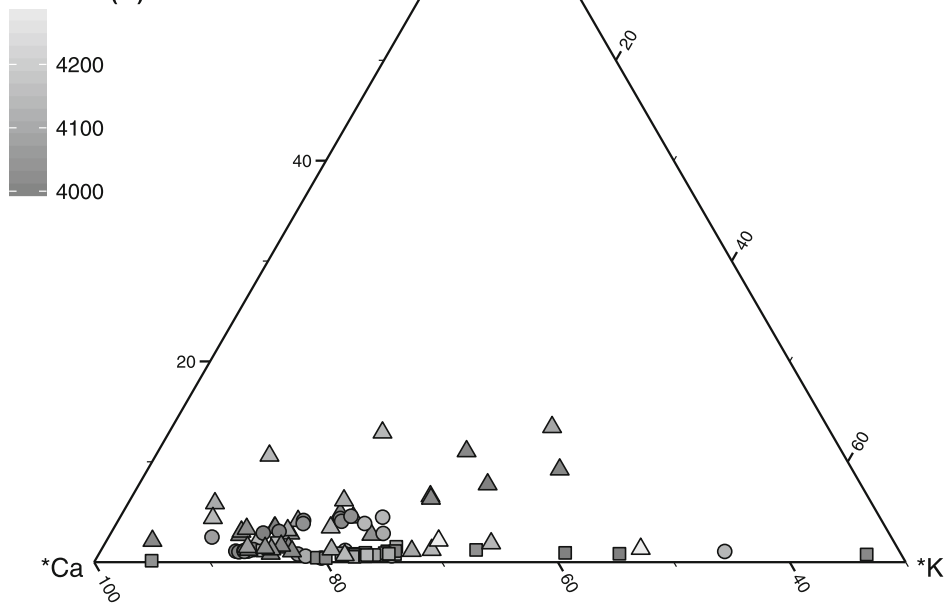

(b)

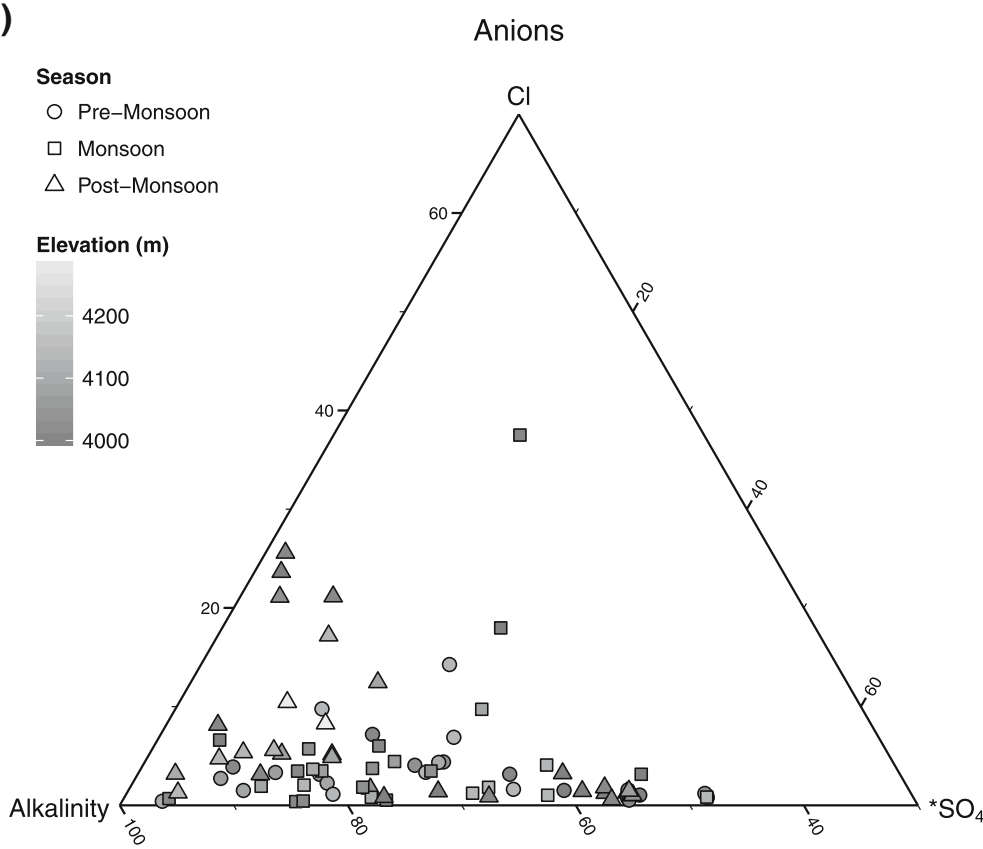

Fig. 7 Ternary diagrams by season (symbol type) and elevation (fill shade). a Sea-salt-corrected cations $* \mathrm{Ca},{ }^{*} \mathrm{Na}$, and $* \mathrm{~K}$. b Alkalinity, $\mathrm{Cl}$, and sea-salt-corrected $* \mathrm{SO}_{4}$ 

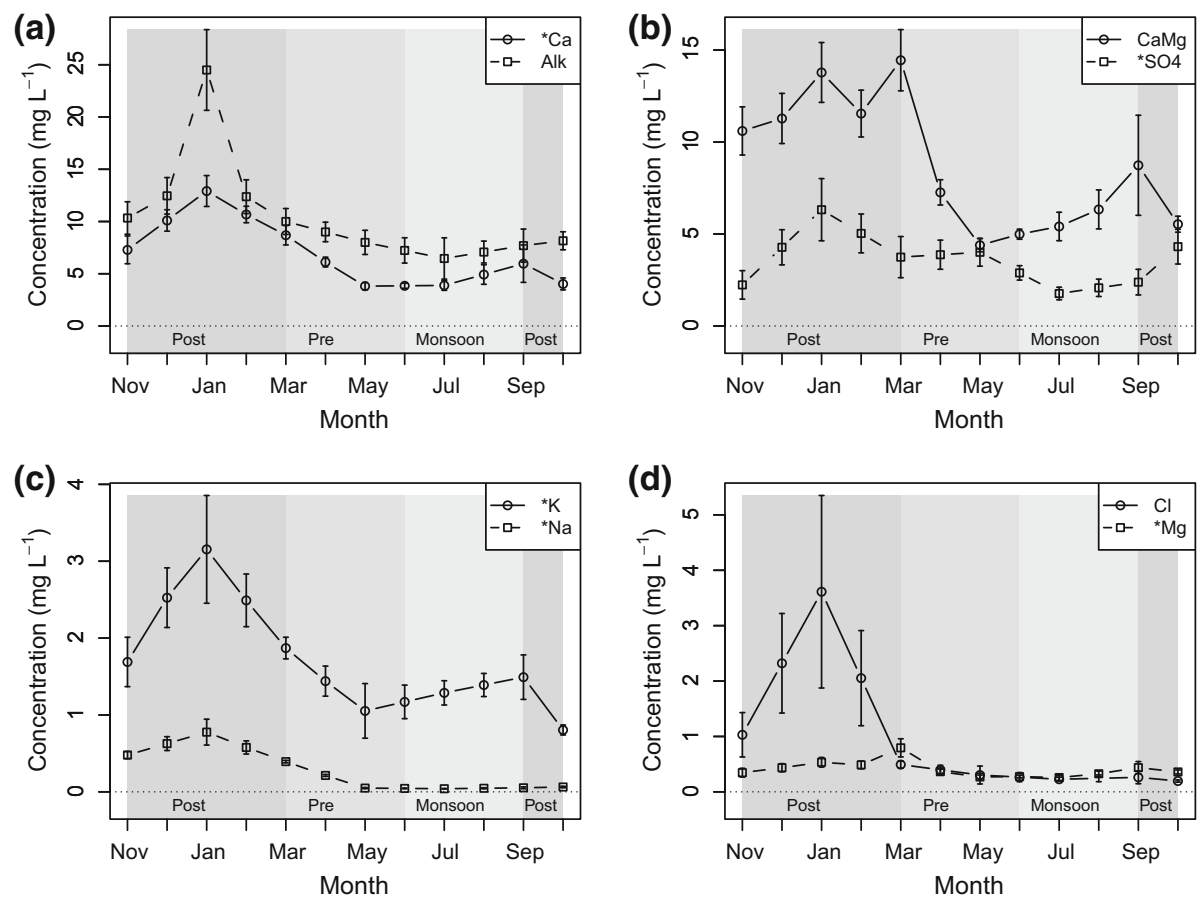

Fig. 8 Average major parameters (ions) over all ponds to emphasize temporal variations. Points at nonsampled months (Dec, Feb, April, June, and August) are linearly interpolated for each pond and then entered into the average. Interpolated points are only used for visualization, not analysis. Seasons are indicated by shading and labeled at the bottom using the following convention: pre-monsoon: March-May; monsoon: June-September, post-monsoon October-February

\subsection{Hypothesis 4: Seasonal Variability of Chemical Compositions}

Figure 8 shows high concentrations for December or January when water discharge is low and surface is frozen, thus rejecting ions in the ice and increasing concentration in water. Then, concentration decreases by dilution when water starts to melt and leading to a minimum in the pre-monsoon months of May and June. Subsequently, there is an increase with the monsoon due to the runoff.

In general, all the major base cations showed highest concentration during the postmonsoon season followed by pre-monsoon and monsoon season. Paired $t$ test of maxima and minima values in the year across ponds for each water parameter yielded significant differences for all parameters. The $p$ values obtained are SS 0.014 , alkalinity $1.2 \times 10^{-5}, \mathrm{~F}$ $0.006, \mathrm{Cl} 0.026, \mathrm{NO}_{3} 0.0006, * \mathrm{SO}_{4} 1.2 \times 10^{-5}$, DOC 0.02, TDN $0.0003, * \mathrm{Na} 0.0005, * \mathrm{~K}$ $0.0002, * \mathrm{Mg} 3.6 \times 10^{-6},{ }^{*} \mathrm{Ca} 6.8 \times 10^{-6}$, and $\mathrm{Si} 2.3 \times 10^{-7}$. These results allow to reject the $\mathrm{H} 0$ corresponding to hypothesis 4 , and therefore, we conclude that there are significant differences between the maximum and minimum values observed in the year.

Calcium, sodium, potassium, and magnesium follow the seasonal pattern (Fig. 8a, c, d), except that higher magnesium is delayed to the end of the post-monsoon (Fig. 8d). Not shown in the figure, it is worth noting that pond P7 showed exceptionally high concentration of base cations after sea-salt correction during the monsoon, which is probably due 
(a)

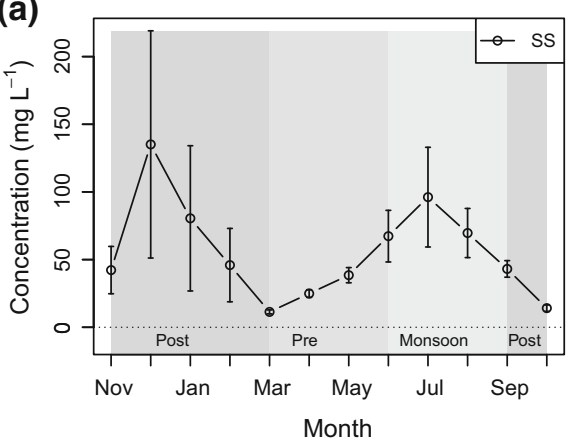

(c)

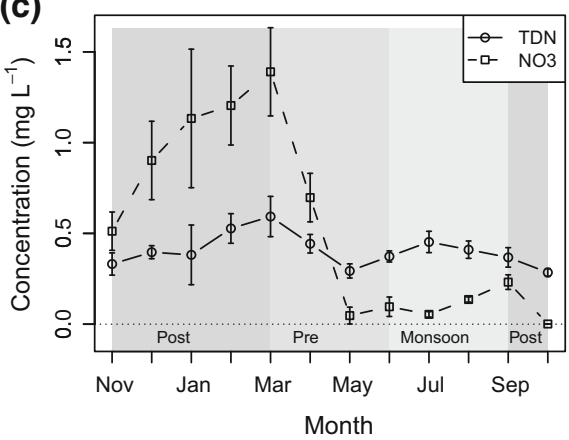

(b)

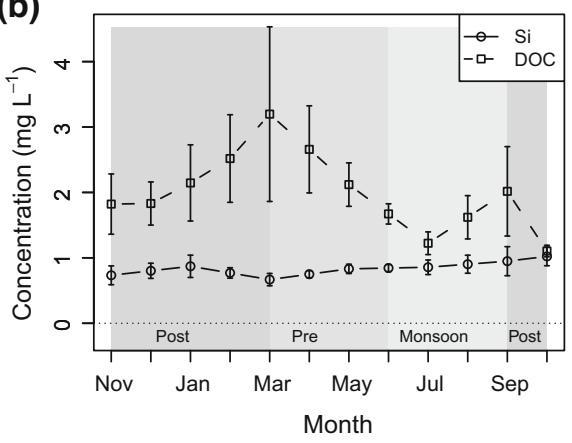

(d)

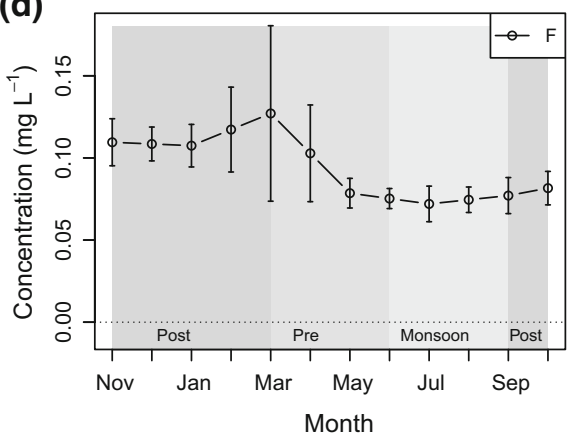

Fig. 9 Average SS and chemical parameters over all ponds to emphasize temporal variations. Points at nonsampled months (Dec, Feb, April, June, and August) are linearly interpolated for each pond and then entered into the average. Interpolated points are only used for visualization, not analysis. Seasons are indicated by shading and labeled at the bottom using the following convention: pre-monsoon: March-May; monsoon: June-September, post-monsoon October-February

to moraine fall and high hydrolysis condition. During monsoon, moraine fall events were observed frequently and water becomes highly turbid. Pond P7 is located at the main flow of the debris, and hence, the availability of fresh minerals and high hydrolysis condition at this site accelerates the dissolution process.

In general, anions also showed highest concentration during the post-monsoon followed by pre-monsoon and monsoon, as illustrated by alkalinity, sulfate, and chloride (Fig. 8a, b, d). Silicon also showed higher concentration during post-monsoon decreasing toward the pre-monsoon; but then, it follows an increasing trend which we ascribe to rock fall, moraine fall, and change in hydrological regime (Fig. 9b).

Other parameters also exhibit high concentrations in the post-monsoon, but the highest concentration of DOC, TDN, and nitrate was delayed to the end of the post-monsoon (Fig. 9b, c). DOC shows lowest concentration in monsoon months possibly because of the effect of dilution. Not shown in the figure, it is worth noting that pre-monsoon DOC values showed an increasing trend with altitude except for pond P1 near Lirung outlet. SS exhibits a second peak during the monsoon probably due to high discharge and higher frequency of landslides, thus causing the flows to carry higher loads of suspended matter (Fig. 9a). The high and very variable values of SS for December are interpolated and cannot be interpreted as certain. TDN shows a similar increase in the monsoon months (Fig. 9c). Not illustrated by the figure, pond P10 showed the highest concentration of TDN during pre- 
monsoon and monsoon seasons, while the isolated pond P2 showed the lowest concentration during post-monsoon season.

Nitrate showed strong seasonal variation pattern with highest concentration in postmonsoon followed by pre-monsoon and monsoon values (Fig. 9c). This variation pattern is probably due to the influence of livestock and change in flow regime due to seasons. Fluoride showed the same seasonal variation trend (Fig. 9d).

\section{Discussion}

\subsection{Overview and Composition of Major Ions}

It is well-known that sea-salt-contributed aerosols impact major ions observed in watersheds (Stallard and Edmond 1981; McDowell et al. 1990; Bhatt and McDowell 2007); therefore, we evaluated these impacts in our study area. We found that calcium and sodium are the least and the most impacted element by marine aerosols, respectively, and that the contribution of marine aerosols to the total dissolved load appears to be minor advocating the lithological control on dissolved matter as reported by earlier studies (Dalai et al. 2002; Bhatt et al. 2008, 2009). The high contribution to sodium and potassium after sea-salt correction among the ponds within high Himalaya region is due to the higher content of silicate minerals in the basin compared to the lower elevation of the landscape (Bhatt et al. 2009).

The contribution to sodium and potassium after sea-salt correction accounts for $32 \%$ of the total sum of base cations, suggesting that the contribution to these ions is mainly due to intense dissolution of silicate minerals within the basin. The contribution to sodium and potassium after sea-salt correction resulted much higher than those in the low-elevation mid-mountains and Tarai region in southern part of Nepal probably due to the variation in lithology of the basin (Bhatt et al. 2009).

We found sulfate concentration many times higher than in most of the largest river systems of the world and in the fastest weathering regimes of a silicate terrane on the earth surface (McDowell and Asbury 1994; Meybeck and Ragu 1997; Gaillardet et al. 1999; Bhatt and McDowell 2007; Tartai et al. 1998; Bhatt et al. 2014a).

Takeuchi et al. (2012) found that various organisms such as insects, copepods, and algae live in ponds in the debris-covered area of this glacier. These authors found insects and algae in the very clear type of pond (blue type in our classification), insects only in the slightly turbid type of pond (yellow type in our classification), and no living organisms in highly turbid type of pond surrounded by ice walls (green type of pond in our classification). Thus, we suggest that the distribution of microorganisms by type of pond is mainly related to inorganic carbon, which varies according to pond color. Blue types of pond formed many years ago and are isolated from the main flow of the debris, whereas highly turbid green types of ponds formed recently and are mostly surrounded by big rocks, boulders, and cobbles. Yellow types of ponds are within the main channel and erosionprone area; whereas the green types of ponds formed recently within the debris-prone area but are surrounded with ice walls.

\subsection{Hypothesis 1: Elevation Trends of Measured Chemical Parameters}

Some chemical parameters showed changes with elevation in this steep gradient $(300 \mathrm{~m}$ elevation change in a distance of $2 \mathrm{~km}$ ). Higher concentrations of major solutes and 
dissolved inorganic carbon species in the lower-elevation ponds are probably due to the influence of hydrological flow path, high residence time (comparatively flat surface), higher temperature (absence of big ice walls), and abundant availability of fresh reactive minerals due to physical erosion transported through the debris area. Altitudinal control of solute release is documented in other systems, for example, in the southern Swiss Alps (Drever and Zobrist 1992), in the Santa Rosa Mountains in the USA (Riebe et al. 2004), along the Himalayan river systems in central Nepal (Bhatt et al. 2009), along the Himalayan rivers (France-Lanord et al. 2003), and in the Everest region of Nepal (Baumler and Zech 1994).

TDN and DOC did not show elevation trends. Variations in TDN and ammonium are primarily due to the variation in livestock influence and human seasonal settlement. DOC variation may be due to spatial variability of organic-rich sediments and DOC thermal degradation. The increase in organic carbon in the sediment reservoir is due to Himalaya weathering affecting the carbon cycle in the region (France-Lanord and Derry 1997). The consumption of $\mathrm{CO}_{2}$ by the silicate weathering in the Ganga and Yamuna watersheds in the Himalayan region is balanced by the release of $\mathrm{CO}_{2}$ through weathering of organic-rich materials like black shale from the basin further suggests the presence of organic-rich materials in the high Himalaya region (Dalai et al. 2002). Furthermore, it has been documented that erosion from the Himalayan basin delivers high amount of organic carbon to the Bay of Bengal (Ittekkot 1988; Subramanian and Ittekkot 1991; France-Lanord and Derry 1997).

In this high Himalaya basin, the $\mathrm{pCO}_{2}$ appeared low since $\mathrm{CO}_{2}$ is quickly absorbed by the minerals during the dissolution processes because the glacier meltwater is diluted and reaction rate is fast. Bicarbonate appeared as a dominant inorganic carbon species, suggesting that the rate of dissolution controls carbonate chemistry.

Silicon did not show significant elevation trends but showed exceptional values in ponds 7 and 13. High concentration of silicon at the central pond is linked directly with high temperature and high-flow conditions, and the abundant availability of fresh reactive mineral surfaces. Some earlier studies have documented the role of temperature and runoff on the dissolution of silicate minerals (Amiotte Suchet and Probst 1993; McDowell and Asbury 1994; Dorn and Brady 1995; White and Blum 1995; Ludwig et al. 1998; Gaillardet et al. 1999; France-Lanord et al. 2003; Krishnaswami and Singh 2005; Wolff-Boenisch et al. 2009). The lower concentration of silicon was observed in the ponds that were covered with ice cliffs and rocks, whereas the higher concentration was observed in the ponds that are covered with moraine walls and those conducting the main water flow. A variation in mineral surface area, controlled by physical denudation rates, plays a great role on the variability in silicon concentration within the basin. Navarre-Sitchler and Brantley (2007) found that weathering advance rates vary over seven orders of magnitude when compared across multiple scales.

\subsection{Hypothesis 2: Seasonal Changes in Elevation Trends}

There are more instances of elevation patterns in the post-monsoon season than in the other seasons. Elevation trends are modulated by seasonality possibly because higher flows in the monsoon redistribute concentration among ponds and freezing in the winter months, which occurs in the post-monsoon, accentuates concentration differences. Subsequent melting will diminish concentration differences in most instances. Sulfate shows significant elevation differences regardless of season; however, the patterns are opposite and less significant in the monsoon. 
Sulfide oxidation is also dependent on the hydrolysis condition of the ponds; hence, the more production of sulfate in lower-elevation sites releases more solutes and bicarbonate due to enhanced dissolution process with high runoff. The high Himalayan region has high content of sulfur-bearing minerals, but the hydrolysis condition is lower than the lowelevation region (France-Lanord et al. 2003; Bhatt et al. 2009).

\subsection{Hypothesis 3: Weathering Extent and Controlling Parameters}

Generally, it appeared that sulfide oxidation has a dominant role in the dissolution processes within high Himalaya region based on the high sulfate content and appearance of rusty precipitation among some ponds and appearance of rocks within debris area supporting the presence of pyrite. Dominance of calcium and sodium among base cations and the dominance of sulfate and alkalinity mainly as bicarbonate among anions suggest that dissolution of carbonate and aluminosilicate coupled with sulfide oxidation within the basin appeared as a dominant geochemical process which controls the major solutes. Sulfide oxidation coupled with carbonate dissolution has been observed in subglacial drainage basins within Himalaya and other glacierized basins of the world (Tranter and Raiswell 1991; Bartarya 1993; Tranter et al. 1993; Fairchild et al. 1994; Galy and France-Lanord 1999; Hasnain and Thayyen 1999; Pandey et al. 1999; Chen et al. 2002; Hodson et al. 2002; Millot et al. 2003; Bhatt et al. 2000, 2007, 2008, 2009, 2014a; Wolff-Boenisch et al. 2009).

The strong relationship between $* \mathrm{Mg}$ and $* \mathrm{Ca}$ and $* \mathrm{SO}_{4}$ indicates that these ions are derived from related processes. Our study area is underlain by high-grade metamorphic rock consisting biotite, quartz, and plagioclase. Biotite $\mathrm{KMg}_{3} \mathrm{AlSi}_{3} \mathrm{O}_{10}(\mathrm{OH})_{2}$ appears as dominant silicate mineral, so the source of $* \mathrm{Mg}$ is the biotite dissolution. During the process of pyrite oxidation, the dissolution process of aluminosilicates including biotite and carbonate also becomes intense. So we observe the strong relationship between $* \mathrm{SO}_{4}$ and $* \mathrm{Mg}$, and $* \mathrm{SO}_{4}$ and $* \mathrm{Ca}+* \mathrm{Mg}$. The additional $\mathrm{Mg}$ could be contributed from the dissolution of dolomites as thick beds of gray silicious dolomites are found in high mountain region in central Nepal. The source of calcium is primarily from Ca-plagioclase $\mathrm{CaAl}_{2} \mathrm{Si}_{2} \mathrm{O}_{8}$ and carbonate dissolution within the basin.

The calculated average ratios of $\mathrm{Si} /(* \mathrm{Na}+* \mathrm{~K})$ among the ponds within Lirung debris areas appeared lower than the calculated ratios from Langtang-Narayani river system in central Nepal Himalayas (unpublished data) and much lower than the calculated ratios from different positions of the Rio Icacos (which drains a tropical rain forest) that has the fastest documented weathering rates of any silicate terrain in the world (McDowell and Asbury 1994; White and Blum 1995; Bhatt and McDowell 2007). The wide variation in Si/ $(* \mathrm{Na}+* \mathrm{~K})$ ratio in our study suggests spatial variation in weathering extent within the study basin. During the dissolution process, the ratio of $\mathrm{Si} /(* \mathrm{Na}+* \mathrm{~K})$ for $\mathrm{Na}$-feldspar to beidellite gives 1.7 , to kaolinite gives 2 , and to gibbsite gives 3 , and $\mathrm{K}$-feldspar to illite gives 3 (Huh et al. 1998). Dalai et al. (2002) found $\mathrm{Si} /\left({ }^{*} \mathrm{Na}+{ }^{*} \mathrm{~K}\right)$ average ratios of 1.2 and also with wide variation along the Yamuna river system suggesting low extent of silicate weathering within drainage basin. The ratio of $\mathrm{Si} /\left(* \mathrm{Na}+{ }^{*} \mathrm{~K}\right)$ was very small in Siberian Rivers compared to the streams of the Guayana Shield and streams of Puerto Rico (Huh et al. 1998; Edmond et al. 1995; Bhatt and McDowell 2007). The high extent of weathering rate within tropical regions such as the Guayana Shield and Puerto Rico is probably due to regimes of high precipitation and high temperature. 


\subsection{Hypothesis 4: Seasonal Variability of Measured Chemical Parameters}

In general, the seasonal pattern for major anions and cations was similar, showing the highest concentration during the post-monsoon, a decrease toward the pre-monsoon, and slight increase in the monsoon. During the post-monsoon season, the temperature drops and glacier melting decreases, and as a consequence, flow decreases and concentration becomes higher than during the pre-monsoon and monsoon seasons. An exception to the general pattern is $\mathrm{Mg}$, which had a delayed peak toward the end of the post-monsoon, which was also observed for DOC, TDN, and nitrate. Another exception to the general pattern is the increasing trend of silicon with time probably due to favorable hydrolysis condition and abundant availability of fresh reactive mineral surfaces due to intense physical erosion. Furthermore, pyrite oxidation also becomes more intense under favorable hydrolysis condition and high physical erosion-prone area which releases abundant sulfate and supply protons that accelerate the dissolution process.

SS and TDN showed a different seasonality trend to major chemical species, since there was an increase in concentration during the monsoon season. We explain this effect by high discharge and higher frequency of landslides, thus causing the flows to carry higher loads of suspended matter. Also, increased flow carries contribution from decomposed vegetation and livestock manure from nearby area. Higher SS concentrations occur in the post-monsoon but are highly variable; a high post-monsoon concentration was observed at pond P1 close to outlet point due to mixing of highly turbid main flow to the pond.

DOC, TDN, and nitrate showed a slightly different seasonal variation trend from major ions (except $\mathrm{Mg}$ ) since the highest concentration is delayed to the latest part of the postmonsoon season. The high concentration of DOC, TDN, and nitrate in later part of the post-monsoon is primarily due to inputs from livestock (yaks, horses, sheep) activities and decomposed shrub and grass from nearby area.

\subsection{Comparison of Average Chemistry with Same and Different Basins of the World}

The average chemical compositions of the supraglacial ponds in the debris-covered area of Lirung glacier are compiled with the chemical compositions of the same and different basins of the world (Table 5). The concentrations of DOC in supraglacial ponds appeared nearly the same as river water samples in high-altitude areas of the same region but the export rate of DOC calculated threefold higher in low-elevation sites of the LangtangNarayani river system than the high-elevation sites in the same area (unpublished data). The DOC of these supraglacial ponds is threefold lower than a pond in the Kathmandu valley, Nepal, and tenfold lower than a heavily urbanized basin (Bagmati River) in the Kathmandu valley, probably due to difference in vegetation, anthropogenic inputs, and temperature (Bhatt et al. 2013, 2014b).

The alkalinity of supraglacial ponds appeared comparable with the Tatra basin of Europe and lower than the Colorado Rocky Mountain area and Cascade lake in Washington of USA, Khumbhu basin within Everest region of Nepal and Lirung outlet point of the same region of Nepal and much lower than the lakes of Spiti and Pandoh basins of India (Axtman and Stallard 1995; Reynolds et al. 1995; Musselman et al. 1996; Henriksen et al. 1997; Tartari et al. 1998; Bhatt et al. 2000, 2007; Das and Dhiman 2003; Borowiak et al. 2006; Anshumali and Ramanathan 2007). The alkalinity of glacier meltwater at the Lirung out point is quite comparable with the Southern Cascade lakes and lakes from rocky mountain areas in Colorado, which is slightly higher than the Tatra basin in Europe and 


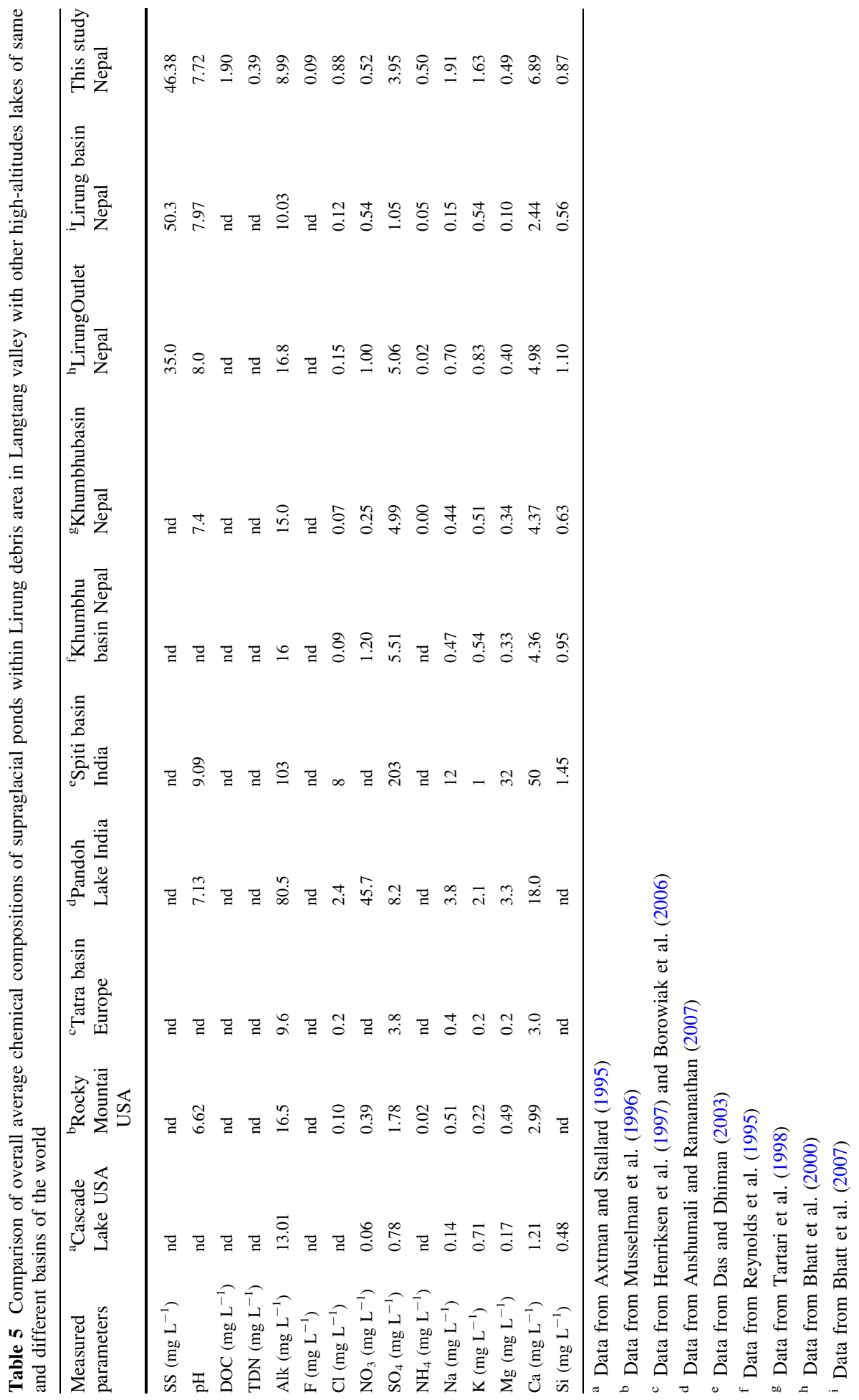


much lower than Pandoh Lake and Spiti basin in India. The difference in alkalinity is primarily related with flow regime of the basins - high alkalinity appeared with the highflow condition area. The extraordinarily high concentration of alkalinity in the lakes of Spiti and Pandoh basins is probably due to the availability of carbonates and high temperature than the other basins in the same region and in the world. The measured nitrate is much higher than the Southern Cascade lakes and rocky mountain areas in Colorado, comparable with other Himalayan basin in Nepal, and much lower than Pandoh Lake probably due to variation in aquatic species. The extraordinarily high concentration of nitrate in Pandoh Lake is probably due to the input from anthropogenic sources. The concentration of sulfate appeared much higher in the Himalayan region than the North American and European basins probably due to variation in sulfide-bearing minerals.

Base cations showed higher concentration in the Himalayan basins than the North American and European basins possibly due to variations in carbonate rocks and temperature. Silicon concentration appeared comparable in the same basin, Khumbhu basin in the Everest region of Nepal, higher than Southern Cascade lakes, and much lower than the Spiti basin in India. The concentrations of major solutes among supraglacial ponds appeared lower than the concentration of rivers in the high-altitude region of the same area advocating the role of hydrolysis condition and climate primarily temperature controls the dissolution rates of the minerals. The variation in minerals, hydrolysis condition, and climate primarily temperature controls the spatial variability in chemistry of high-altitude ponds and lakes in Himalayas, Europe, and North American regions.

\section{Conclusions}

Using four research hypotheses, we have examined elevation trends, and their control by seasonality, dominant geochemical processes, and seasonal dynamics in the supraglacial ponds in the debris-covered area of Lirung glacier in central Nepal Himalayas. We have been able to reject the null $\mathrm{H} 0$ for all hypotheses. Concentration of some parameters showed a decreasing trend with elevation but with high variability and modulation by seasons, being more prevalent in the post-monsoon. Sulfate shows significant elevation trends regardless of the season, although the trend is also affected by the monsoon. Chemical concentration of all parameters resulted highest during the post-monsoon, decreasing toward the pre-monsoon, and slight increases in the monsoon season, advocating the major control of seasonality on chemical concentrations. Sulfate resulted strongly correlated with magnesium and with calcium, as well as with the sum of magnesium and calcium. This result indicates that the dominant geochemical processes are chemical weathering of carbonate and silicate minerals fueled by dissolution of pyrite. The contribution to marine aerosols appeared to be relatively small in the total mass of solutes in the debris-covered area. The variations in flow condition, presence of ice, availability of fresh reactive mineral surfaces - physical erosion, variation in temperature, and site-specific conditions are prime causes for the variation in chemical compositions among the pond types.

Acknowledgments The authors would like to thank Tom Jäppinen, Lisette Kretzschmann, and Ronny Lauerwald for their help in laboratory and analysis work. The authors are grateful to Kedar Rijal, Anil Shrestha, and Bijaya Pokhrel for their help and cooperation in field work. Thanks to Quinga Tamang, Mingma Tamang, Deepak Bhatt, Gyanendra Pant, Gyan Shrestha, Rajan Subedi, and other members of the field campaign for their help and cooperation during the sampling. The authors would like to thank the editor for suggestions and three anonymous reviewers for their insightful comments which improve the paper 
greatly. This research work was supported through the Cluster of Excellence 'CliSAP' (EXC177), KlimaCampus-University of Hamburg, funded through the German Science Foundation (DFG).

\section{Compliance with Ethical Standards}

Conflicts of interest Disclosure of potential conflicts of interest.

Ethical Standard We maintain the integrity of the research and its presentation achieved by following the rules of good scientific practice. We have followed the principles of ethical and professional conduct.

\section{References}

Amiotte Suchet P, Probst JL (1993) Modeling of atmospheric $\mathrm{CO}_{2}$ consumption by chemical weathering of rocks-application to the Garonne, Congo and Amazon Basins. Chem Geol 107(3-4):205-210

Anshumali, Ramanathan AL (2007) Seasonal variation in the major chemistry of Pandoh Lake, Mandi District, Himachal Pradesh, India. Applied Geochemistry 22(8):1736-1747

APHA, American Public Health Association (1995) Standard method for the examination of water and waste water. 19th Edition. Edited by Eaton AD, Clesceri LS, Greenberg AE. American Public Health Association, 1015 Fifteenth Street, NW. Washington, DC 20005, USA

Axtman EV, Stallard RF (1995) Chemical weathering in the South Cascade Glacier basin, comparison of subglacial and extra-glacial weathering. In: Tonnessen KA, Williams MW, Tranter M (eds) Biogeochemistry of seasonally snow-covered catchments. IAHS Publ. No. 228, pp 431-439

Barnard PL, Owen LA, Finkel RC, Asahi K (2006) Landscape response to deglaciation in a high relief, monsoon-influenced alpine environment, Langtang Himal, Nepal. Quaternary Sci Reviews 25(17-18):2162-2176

Bartarya SK (1993) Hydrochemistry and rock weathering in a subtropical lesser Himalayan river basin in Kumaun, India. J Hydrol 146(1-4):149-174

Baumler R, Zech W (1994) Soils of the high-mountain region of eastern Nepal—classification, distribution and soil formation process. Catena 22(2):85-103

Benn DI, Bolch T, Hands K, Gulley J, Luckman A, Nicholson LI, Quincey D, Thompson S, Toumi R, Wiseman S (2012) Response of debris-covered glaciers in the Mount Everest region to recent warming, and implications for outburst flood hazards. Earth-Sci Rev 114:156-174

Bhatt MP, McDowell WH (2007) Controls on major solutes within the drainage network of a rapidly weathering tropical watershed. Water Resour Res 43:W11402. doi:10.1029/2007WR005915

Bhatt MP, Masuzawa T, Yamamoto M, Sakai A, Fujita K (2000) Seasonal changes in dissolved chemical composition and flux of melt water draining from Lirung glacier in the Nepal Himalayas. In: Proceedings of a workshop on Debris-Coved Glaciers held at Seattle, Washington, USA. IAHS Publ no 264, pp 277-288

Bhatt MP, Masuzawa T, Yamamoto M, Takeuchi N (2007) Chemical characteristics of pond waters within the debris area of Lirung Glacier in Nepal Himalaya. J Limn 66(2):71-80

Bhatt MP, Masuzawa T, Yamamoto M, McDowell WH (2008) Chemical weathering in central Himalaya: dissolved silica dynamics in glacier meltwater. International conference on hydrology and climate change in mountainous area (ICHCC), SOHAM-UNESCO, pp 162-179

Bhatt MP, Masuzawa T, Yamamoto M, Gardner KH (2009) Spatial variations in chemical compositions along Langtang-Narayani river system in central Nepal. Environ Geol 57:557-569. doi:10.1007/ s00254-008-1325-X

Bhatt MP, Bhatt S, Gaye B (2013) Controls on pond water chemistry within Kathmandu, Valley, Nepal. Int J Lakes Rivers 6(2):153-172

Bhatt MP, Bhatt S, Gaye B (2014a) Controls on Gosaikunda Lake Chemistry within Langtang National Park in High Himalaya, Nepal. Int J Geosci 5:1100-1115. doi:10.4236/ijg.2014.510094

Bhatt MP, McDowell WH, Gardner KH, Hartmann J (2014b) Chemistry of heavily urbanized Bagmati river system in Kathmandu Valley, Nepal: export of organic matter, nutrients, major ions, silica and metals. Environ Earth Sci. doi:10.1007/s12665-013-2494-9

Bookhagen B (2010) Appearance of extreme monsoonal rainfall events and their impacts on erosion on the Himalaya. Geomat Nat Hazards Risk 1(1):37-50

Borowiak D, Polkowska Z, Przyjazny A (2006) The hydrochemistry of high altitude lakes in selected mountain ranges of central and southern Europe. Limnol Rev 6:21-30 
Chabaux F, Riotte J, Clauer N, France-Lanord C (2001) Isotopic tracing of the dissolved U fluxes of Himalayan Rivers: implications for present and past $U$ budget of the Ganges-Brahmaputra system. Geochim Cosmochim Acta 65(19):3201-3217

Chen J, Wang F, Xia X, Zhang L (2002) Major element chemistry of the Changjiang (Yangtze River). Chem Geol 187:231-255

Dalai TK, Krishnaswami S, Sarin MM (2002) Major ion chemistry in the headwaters of the Yamuna river system: chemical weathering, its temperature dependence and $\mathrm{CO}_{2}$ consumption in the Himalaya. Geochim Cosmochim Acta 66(19):3397-3416

Das BK, Dhiman SC (2003) Water and sediment chemistry of high Himalayan lakes in the Spiti Valley: control on weathering, provenance and tectonic setting of the basin. Environ Geol 44:717-730

DMG, Department of Mines and Geology (1980) Geological map of Central Nepal. Department of Mines and Geology, His Majesty's Government of Nepal, Kathmandu, Nepal

DMG, Department of Mines and Geology (1994) Geological map of Nepal. Department of Mines and Geology, His Majesty's Government of Nepal, Kathmandu, Nepal

Dorn RI, Brady PV (1995) Rock-based measurement of temperature dependent plagioclase weathering. Geochim Cosmochim Acta 59:2847-2852

Drever JI (1988) The Geochemistry of Natural Waters, 2nd edn. Prentice Hall, Englewood Cliffs

Drever JI, Zobrist J (1992) Chemical weathering of silicate rocks as a function of elevation in the southern Swiss Alps. Geochim Cosmochim Acta 56:3209-3216

Edmond JM, Palmer MR, Measures CI, Grant B, Stallard RF (1995) The fluvial geochemistry and denudation rate of the Guayana Shield in Venezuela, Columbia and Brazil. Geochim Cosmochim Acta 59:3301-3325

Evans MJ, Derry LA, France-Lanord C (2004) Geothermal fluxes of alkalinity in the Narayani river system of central Nepal. Geochem Geophys Geosyst 5(8):Q08011. doi:10.1029/2004GC000719

Fairchild IJ, Bradby L, Sharp M, Tison JL (1994) Hydrochemistry of carbonate terrains in alpine glacial settings. Earth Surf Proc Land 19(1):33-54

France-Lanord C, Derry L (1997) Organic carbon burial forcing of the carbon cycle from Himalayan erosion. Nature 390:65-67

France-Lanord C, Evans M, Hurtrez JE, Riotte J (2003) Annual dissolved fluxes from central Nepal rivers: budget of chemical erosion in the Himalayas. Comptes Rendus Geosci 335(16):1131-1140

Fukusima Y, Kawashima K, Suzuki M, Ohta T, Motoyama K, Kubota H, Yamada T, Bajracharya OR (1987) Runoff characteristics in three glacier-covered watershed of Langtang Valley, Nepal Himalaya. Bull Glacier Res 5:11-18

Gabet EJ (2007) A theoretical model coupling chemical weathering and physical erosion in land-slide dominated landscapes. Earth Planet Sci Lett 264:259-265

Gabet EJ, Wolff-Boenisch D, Langner H, Burbank DW, Putkonen J (2010) Geomorphic and climatic controls on chemical weathering in the High Himalayas of Nepal. Geomorphology 122:205-210

Gaillardet J, Dupre B, Louvat P, Allegre CJ (1999) Global silicate weathering and $\mathrm{CO}_{2}$ consumption rates deduced from the chemistry of large rivers. Chem Geol 159(17):3-30

Galy A, France-Lanord C (1999) Weathering processes in the Ganga-Brahmaputra basin and the riverine alkalinity budget. Chem Geol 159(1-4):31-60

Garrels RM, Mackenzie FT (1967) Origin of chemical compositions of some springs and lakes. Equilibrium concepts in natural water system, Advanced Chemistry Series 67. American Chemical Society, Washington DC, pp 222-242

Green WT, Stage BR, Preston A, Wagers S, Shacat J, Newell S (2005) Geochemical processes in the Onyx River; Wright Valley, Antarctica: major ions, nutrients, trace metals. Geochim Cosmochim Acta 69(4):839-850

Hartmann J (2009) Bicarbonate fluxes and $\mathrm{CO}_{2}$ consumption by chemical weathering on the Japanese Archipelago: application of multi-lithological model framework. Chem Geol 265:237-271

Hasnain SI, Thayyen RJ (1999) Controls on the major ion chemistry of Dokriani glacier meltwaters, Ganga basin, Garhwal Himalaya, India. J Glaciol 45:87-92

Henriksen A, Mill WA, Kot M, Rzychon D, Wathne BM (1997) Critical loads of acidity to surface waters. A case study from Polish Tatra Mountains. Acid rain research. NIVA Report 29, p 34

Hirschmiller J, Grujic D, Bookhagen B, Coutand I, Huyghe P, Mugnier J-L, Ojha T (2014) What controls the growth of the Himalayan foreland fold-and-thrust belt? Geology 42(3):247-250

Hodson A, Porter P, Lowe A, Mumford P (2002) Chemical denudation and silicate weathering in Himalayan glacier basins: Batura Glacier, Pakistan. J Hydrol 262:193-208

Huh Y, Panteleyev G, Babich D, Zaitsev A, Edmund JM (1998) The fluvial geochemistry of the rivers of eastern Siberia: II. Tributaries of the Lena, Omoloy, Yana, Indigirka, Kolyma, and Anadyr draining the 
collisional/accretionary zone of the Verkhoyansk and Cherskiy ranges. Geochim Cosmochim Acta 62(12):2053-2075

ICIMOD (2011) Glacial lakes and glacial lake outburst floods in Nepal. Nepal, International Centre for Integrated Mountain Development, Kathmandu, p 99

ICIMOD-UNEP (2002) Inventory of glaciers, glacial lakes and glacial lake outburst floods monitoring and early warning systems in the Hindu Kush Himalayan Region-Nepal. International Center for Integrated Mountain Development and United Nations Environmental Program, pp 197

Inger S, Harris BW (1992) Tectonothermal evolution of the High Himalayan crystalline sequence, Langtang Valley, Northern Nepal. J Metamorph Geol 10:439-452

Ittekkot V (1988) Global trends in the nature of organic matter in river suspensions. Nature 332:436-438

Jenkins A, Sloan WT, Cosby BJ (1995) Stream chemistry in the middle hills and mountains of the Himalayas, Nepal. J Hydrol 166(1-2):61-79

Kamiyama K (1984) Lakes and sediments around Yala Glacier. In: Higuchi K (ed) Glacier studies in Langtang Valley. Data Center of Glacier Research, Water Research Institute, Nagoya University, Nagoya, pp 85-89

Kattelmann R (2003) Glacial lake outburst floods in Nepal Himalaya: a manageable hazard? Nat Hazard 28(1):145-154

Keene WC, Pszenny AAP, Galloway JN, Hawley ME (1986) Sea-salt corrections and interpretation of constituent ratios in marine precipitation. J Geophys Res 91(D6):6647-6658

Kirkbride MP (1993) The temporal significance of transitions from melting of calving termini at glaciers in the central Southern Alps of New Zealand. Holocene 3:232-240

Krishnaswami S, Singh SK (2005) Chemical weathering in the river basins of the Himalaya, India. Curr Sci 89(5):841-849

Lliboutry L, Morales B, Pautre A, Schneider B (1977) Glaciological problems set by the control of dangerous lakes in Cordillera Blanca, Peru. I. Historical failure of moraine dams, their causes and prevention. J Glaciol 18:239-254

Ludwig W, Amiotte Suchet P, Munhoven G, Probst JL (1998) Atmospheric $\mathrm{CO}_{2}$ consumption by continental erosion: present-day controls and implications for the last glacial maximum. Global Planet Change 16-17:107-120

Lupker M, France-Lanord C, Galy V, Lave J, Gaillardet J, Gajurel AP, Guilmette C, Rahman M, Singh SK, Sinha R (2012) Predominant floodplain over mountain weathering of Himalayan sediment (Ganga basin). Geochim Cosmochim Acta 84:410-432

McDowell WH, Asbury CE (1994) Export of Carbon, Nitrogen, and Major ions from three tropical montane watersheds. Limnol Oceanogr 39(1):111-125

McDowell WH, Sanchez CG, Asbury CE, Ramos Perez CR (1990) Influence of sea salt aerosols and long range transport on precipitation chemistry at El Verde, Puerto Rico. Atmos Environ 24(11):2813-2821

Meybeck M, Ragu A (1997) River Discharges to the Oceans: An assessment of suspended solids, major ions and nutrients. Nairobi, UNEP/WHO, Environment of Information and Assessment Division, UNEP, p 245

Millot R, Gaillardet J, Dupre B, Allegre CJ (2002) The global control of silicate weathering rates and the coupling with physical erosion: new insights from rivers of the Canadian Shield. Earth Planet Sci Lett 196:83-98

Millot R, Gaillardet J, Dupre B, Allegre CJ (2003) Northern latitude chemical weathering rates: clues from the Mackenzie River Basin, Canada. Geochim Cosmochim Acta 67(7):1305-1329

Ming J, Xiao C, Du Z, Yang X (2013) An overview of black carbon deposition in high Asia glaciers and its impact on radiation balance. Adv Water Resour 55:80-87

Musselman RC, Hudnell L, Williams MW, Summerfeld RA (1996) Water chemistry of rocky mountain front range aquatic ecosystems. Research Paper RM-RP-325, USDA Forest Service, Fort Collins, CO, USA, p 13

Navarre-Sitchler A, Brantley SL (2007) Basalt weathering across scales. Earth Planet Sci Lett 261:321-334

Pandey SK, Singh AK, Hasnain SI (1999) Weathering and geochemical processes controlling solute acquisition in Ganga headwater-Bhagirathi river, Garhwal Himalaya, India. Aquat Geochem 5(4):357-379

Quade J, English N, DeCelles PG (2003) Silicate versus carbonate weathering in the Himalaya: a comparison of the Arun and Seti river watersheds. Chem Geol 202(3-4):275-296

Reynolds B, Chapman PJ, French MC, Jenkin A, Wheater HS (1995) Major, minor and trace element chemistry of surface waters in the Everest region of Nepal. In: Tonnessen KA, Williams MW, Tranter M (eds) Biogeochemistry of seasonally snow-covered catchments. IAHS Publ no 228, pp 405-412

Richardson SD, Reynolds JM (2000) An overview of glacial hazards in the Himalayas. Quat Int 65/66(1):31-47

Riebe CS, Kirchner JW, Finkel RC (2004) Sharp decrease in long-term chemical weathering rates along an altitudinal transects. Earth Planet Sci Lett 218(3-4):421-434 
Sakai A, Takeuchi N, Fujita K, Nakawo M (2000) Role of supraglacial ponds in the ablation process of a debris-covered glacier in the Nepal Himalayas. In: Proceedings of a workshop on debris covered glaciers held at Seattle, Washington, USA. IAHS Publ no 265, pp. 119-130

Sakai A (2012) Glacier lakes in the Himalayas: a review on formation and expansion processes. Global Environ Res 16:23-30

Sakai A, Fujita K (2010) Formation condition of supraglacial lakes on debris-covered glaciers in Himalayas. J Glaciol 56:177-181

Sakai A, Nakawo M, Fujita K (1998) Melt rate of ice cliffs on the Lirung Glacier, Nepal Himalayas. Bull Glacier Res 16:57-66

Scherler D, Bookhagen B, Strecker MR (2011) Spatially variable response of Himalayan glaciers to climate change affected by debris cover. Nat Geosci. doi:10.1038/NGEO1068

Sharp M, Tranter M, Brown GH, Skidmore M (1995) Rates of chemical denudation and $\mathrm{CO}_{2}$ drawdown in glacier-covered Alpine Catchments. Geology 76:195-206

Stallard RF (2000) Tectonic Processes and Erosion. Int Geophys 72:195-229

Stallard RF, Edmond JM (1981) Geochemistry of the Amazon 1. Precipitation chemistry and the marine contribution to the dissolved load at the time of peak discharge. J Geophys Res 86:9844-9858

Stallard RF, Edmond JM (1983) Geochemistry of the Amazon 2. The influence of geology and weathering environment on the dissolved load. J Geophys Res 88(C14):9671-9688

Subramanian V, Ittekkot V (1991) Carbon transport by the Himalayan rivers. In: Degens ET, Kempe S, Richey JE (eds) Biogeochemistry of Major World Rivers, SCOPE. Wiley, Chichester, pp 157-168

SD, Survey Department (1984) Land system map, central development region, Nepal. Topographical Survey Branch, Survey Department. Ministry of Land Reform, HMG, Kathmandu, Nepal

Takeuchi N, Kohshima S (2000) Effect of debris cover on species composition of living organism in supraglacial lakes on a Himalayan glacier. In: Proceedings of a workshop on debris covered glaciers held at Seattle, Washington, USA. IAHS Publ no 264, pp. 267-275

Takeuchi N, Sakai A, Kohshima S, Fujita K, Nakawo M (2012) Variation in suspended sediment concentration of supraglacial lakes on debris covered area of the Lirung glacier in the Nepal Himalayas. Aires Glob Environ Res 16:95-104

Tartari GA, Tartari G, Mosello R (1998) Water chemistry of high altitude lakes in the Khumbu and Imja Khola Valleys (Nepalese Himalayas). Mem Ist Ital Idrobiol 57:51-76

R Development Core Team (2015). R: a language and environment for statistical computing Retrieved 2015, from http://www.R-project.org

Tipper ET, Bickle MJ, Galy A, West AJ, Pomies C, Chapman HJ (2006) The short term climatic sensitivity of carbonate and silicate weathering fluxes: insight from seasonal variations in river chemistry. Geochim Cosmochim Acta 70(11):2737-2754

Tranter M, Raiswell R (1991) The composition of the englacial and subglacial component in bulk meltwaters draining the Gornergletscher, Switzerland. J Glaciol 37:59-66

Tranter M, Brown G, Raiswell R, Sharp M, Gurnell A (1993) A conceptual model of solute acquisition by Alpine glacier meltwaters. J Glaciol 39:573-581

Wadham JL, Hodson AJ, Tranter M, Dowdeswell JA (1998) The hydrochemistry of meltwaters during the ablation season at a high Arctic, polythermal-based glacier, South Svalbard: I. The ablation season. Hydrol Process 12:1825-1849

Watanabe O, Takenaka S, Iida H, Kamiyama K, Thapa KB, Mulmi DD (1984) First results from Himalayan Glacier Boring Project in 1981-1982: Part I Stratigraphic analyses of full depth cores from Yala glacier, Langtang Himal, Nepal. In: Higuchi K (ed) Glacial studies in Langtang Valley. Data Centre for Glacier Research, Water Resources Institute, Nagoya University, Nagoya, Japan, pp 7-23

West AJ, Bickle MJ, Collins R, Brasington J (2002) Small-catchments perspective on Himalayan weathering. Geology 30(4):355-358

West AJ, Galy A, Bickle M (2005) Tectonic and climate controls on silicate weathering. Earth Planet Sci Lett 235(1-2):211-228

White AF, Blum AE (1995) Effects of Climate on chemical weathering in watersheds. Geochim Cosmochim Acta 59(9):1729-1747

Wolff-Boenisch W, Gabet E, Burbank DW, Langner H, Putkonen J (2009) Spatial variations in chemical weathering and $\mathrm{CO}_{2}$ consumption in Nepalese High Himalayan catchments during monsoon season. Geochim Cosmochim Acta 73:3148-3170

WWF-Nepal (2005) An overview of glaciers, glacier retreat, and subsequent impacts in Nepal, India, and China. Nepal, Kathmandu, p 70

Yamada T, Sharma CK (1993) Glacier lakes outburst floods in the Nepal Himalaya. IAHS 218:319-330 